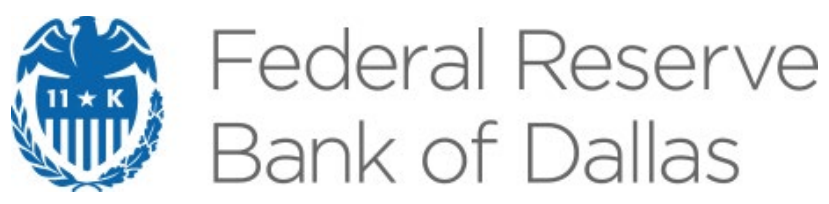

\title{
A Novel MIMIC-Style Model of European Bank Technical Efficiency and Productivity Growth
}

Marwan Izzeldin, Emmanuel Mamatzakis, Anthony Murphy and Mike Tsionas

\section{Working Paper 2012}

Research Department

https://doi.org/10.24149/wp2012

Working papers from the Federal Reserve Bank of Dallas are preliminary drafts circulated for professional comment. The views in this paper are those of the authors and do not necessarily reflect the views of the Federal Reserve Bank of Dallas or the Federal Reserve System. Any errors or omissions are the responsibility of the authors. 


\title{
A Novel MIMIC-Style Model of European Bank Technical Efficiency and Productivity Growth*
}

\author{
Marwan Izzeldin ${ }^{\dagger}$, Emmanuel Mamatzakis $^{\ddagger}$, Anthony Murphy $^{\S}$ and Mike Tsionas ${ }^{ \pm}$
}

May 2020

\begin{abstract}
Using Bayesian Monte Carlo methods, we augment a stochastic distance function measure of bank efficiency and productivity growth with indicators of capitalization, return and risk. Our novel Multiple Indicator-Multiple Cause (MIMIC) style model generates more precise estimates of policy relevant parameters such as returns to scale, technical inefficiency and productivity growth. We find considerable variation in the performance of EU-15 banks over the period 2008 to 2015 . For the vast majority of banks, productivity growth - the sum of efficiency and technical changes - is negative, implying that the industry would benefit from innovation. We show that greater technical efficiency is associated with higher profitability, higher capital, a lower probability of default and lower return volatility.
\end{abstract}

Keywords: Multiple Indicators-Multiple Causes (MIMIC); technical efficiency; productivity growth; EU banks.

JEL Codes: C11, C51, D24, G21.

\footnotetext{
*We thank Gerard Steele and Mike Weiss for helpful comments. The views expressed in the paper are not necessarily those of the Federal Reserve Bank of Dallas or the Federal Reserve System.

$\S$ Corresponding author: Anthony Murphy, Federal Reserve Bank of Dallas, 2200 N. Pearl St., Dallas, TX 75201, Ph. +1 (214) 922-5230, anthony.murphy@dal.frb.org.

${ }^{\dagger}$ Marwan Izzeldin, Lancaster University Management School, Lancaster LA1 4YX, United Kingdom, m.izzeldin@lancaster.ac.uk.

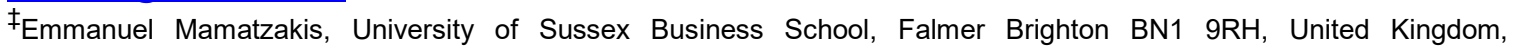
e.mamatzakis@sussex.ac.uk.

${ }^{ \pm}$Mike Tsionas, Lancaster University Management School, Lancaster LA1 4YX, United Kingdom, m.tsionas@lancaster.ac.uk.
} 


\section{Introduction}

In this paper, we propose a novel model for assessing the underlying performance of European banks over the period 2008-2015. Our approach combines the multiple indicator-multiple cause (MIMIC) approach of Jöreskog and Goldberger (1975) with the stochastic frontier approach employed in most of the bank efficiency literature. Specifically, the latent one-sided technical inefficiency random error in our stochastic frontier distance function is reflected in multiple risk, return and capitalization "indicators", as well as being driven by a range of "causes". The inclusion of multiple indicators of technical inefficiency in a stochastic frontier framework is new, and combines structural and non-structural approaches to measuring bank efficiency, e.g. Hughes and Mester (2019). The model is easily implemented using Bayesian methods, fits far better than the basic stochastic frontier distance function, and generates much narrower density intervals for important parameters of interest, including the technical inefficiency and productivity growth of European banks. Allocative as well as technical efficiency may be examined by replacing the stochastic distance frontier with stochastic cost, revenue or profit frontiers.

Chaudhuri, Kumbhakar and Sundaram (2016) used a MIMIC model to examine the technical efficiency of Indian firms. In their model, latent technical inefficiency is driven by "causes" such as age, size, advertising expenses and the debt-to-equity ratio, and is reflected in indicators such as the return on equity and assets (ROE, ROA) and Tobin's Q. Chaudhuri et al. compare the estimates of technical efficiency from the MIMIC model and a stochastic frontier model, where the inputs are the same as the causal variables, and conclude that the MIMIC and stochastic frontier approaches are complementary. Our technical innovation is to show how the MIMIC and stochastic frontier approaches may be combined, and the resulting model estimated using Markov Chain Monte Carlo (MCMC) methods. We do so by augmenting the posterior likelihood with the latent one-sided technical inefficiency random error in the spirit of Albert and Chib (1993) and Greenberg and Chib (2020).

In our model, the indicators of technical inefficiency are the return on assets and equity (ROA and ROE) profitability measures, capitalization, and the Z-score and volatility risk measures. Standard stochastic frontier analyses tend to ignore the endogenous risk-return tradeoff emphasized by Hughes and Mester $(2013,2019)$ and Delis et al. (2017), inter alios. Capitalization, the ratio of equity to total assets, attracts the attention of practitioners, analysts and regulators. Although the effect of changes in capitalization on performance depends on the theory of the banking firm, under the signaling hypothesis, capitalization and performance are positively related. The Z-score has also been frequently used in the 
empirical literature to reflect a bank's probability of insolvency (Demirgüç-Kunt and Huizinga, 2010, Köhler, 2015, Laeven and Levine, 2009). This metric is defined as the number of standard deviations that a bank's return on assets must fall below the mean for the bank to become insolvent. A higher Z-score indicates that a bank is farther from default. The Z-score is considered a better measure of bank risk than the non-performing loan ratio because it captures other factors besides credit risk. Moreover, non-performing loans are traditionally backward looking and highly pro-cyclical. BaselgaPascual et al. (2015) note that profitability, capitalization, and efficiency are significantly inversely related to European bank risk, as measured by the Z-score. ${ }^{2}$

We use our model to study the technical inefficiency and productivity growth of EU-15 banks over the period 2008-2015. Many European banks - especially banks in "peripheral" countries such as Greece, Ireland, Italy, Portugal and Spain - remain under-capitalized and saddled with large portfolios of non-performing loans following the Global Financial Crisis (GFC) and subsequent European sovereign debt crisis (Goddard, Molyneux and Wilson, 2019). The crises showed how exposed banks were to global shocks in such an integrated and interconnected market as the EU. Growing competition in the 1990s and early 2000s reduced their market power and charter values, and incentivized some banks - particularly less efficient ones - to take on greater risks via excessive financial liberalization. Looking ahead, the more efficient and productive European banks will be better positioned to weather future crises.

The paper is organized as follows. Section 2 surveys the somewhat patchy and inconclusive literature on the technical efficiency and productivity growth of European banks, particularly focusing on developments since the GFC. Our MIMIC-style model for measuring bank technical efficiency and productivity growth is set out in Section 3. The posterior distribution of the model, and the Monte Carlo method of inference, are outlined in Section 4. The data are described in Section 5, and the empirical results are presented and discussed in Section 6. Some further model checks are provided in Section 7. Finally, Section 8 is a summary and conclusion.

\section{The Efficiency of European Banks: A Literature Survey}

\footnotetext{
${ }^{2}$ Koutsomanoli-Filippaki and Mamatzakis (2009) explore the dynamic interactions between the risk and efficiency, of European banks. Although they the effects of distance to default shocks on inefficiency are negative and substantial, there is some evidence of a reverse causation.
} 
Many studies look at the trends in, and the convergence of, the efficiency and productivity of European banks. ${ }^{3}$ The creation of the European Union's Single Market for financial services on January 1, 1993 was expected to foster cross-border competition, increase financial integration and boost the efficiency of European banks. Altunbas et al. (2001), Lozano-Vivas et al. (2002), Maudos et al. (2002) and Bos and Schmiedel (2007) are examples of papers documenting significant dispersion in the efficiency of European banks around the time of the introduction of the Single Market. Altunbas et al. (2001) document the wide variation in efficiency across banks and highlight the scope for additional cost savings through reducing managerial and other inefficiencies. They suggest that large banks benefit the most from technical progress, despite lacking a scale economy advantage. Maudos et al. (2002) also highlight the variation in bank efficiency in 10 European Union (EU) countries in the mid -1990s, noting the much greater variation in profit efficiency than cost efficiency. ${ }^{4}$

Berger et al. (2003) suggest that the initial impact of the Single Market was limited to increased consolidation of banks at the local level. Casu and Molyneux (2003) detect a small improvement in European bank efficiency since the Single Market program, but little evidence of convergence. Weill (2009) finds evidence of convergence in cost efficiency, supporting the view that the EU single market program generated greater financial integration. The evidence for the newer EU members is mixed. On the one hand, Kasman and Yildirim (2006) find considerable heterogeneity in cost and profit inefficiency of new EU member banks from Central and Eastern Europe, and little evidence of performance

\footnotetext{
${ }^{3}$ Numerous papers focus on a narrower aspect of European bank efficiency such as one country or one type of bank. For example, Avisoa (2016), Barros et al. (2010), Kontolaimou and Tskouras (2010) and Kuc (2017) study cooperative banks. Lozano-Vivas (1998), Khumbhakar et al. (2001), Tortosa-Austina et al. (2008) and Epure et al. (2011) study Spanish savings banks. Kumbhakar and Lozano-Vivas (2005) look at the impact of deregulation on the productivity of Spanish banks. Ali and Gstach (2000) study the impact of deregulation during 1990-1997 on Austrian banks. Battesse et al. (2000) examine the impact of derulation in the mid-1980s and the subsequent banking crisis on the efficiency and productivity growth of Swedish banks. Pasioras and Kosmidou (2007) examine the profitability of foreign and domestic commercial banks. Lensink et al. (2008) and Giradone et al. (2009) focus on difference in the efficiency related to foreign ownership and ownership structure, respectively. Canhoto and Dermine (2003) and Boucinha et al. (2013) study Portuguese banks, Rossi et al. (2005) banks in Central and Eastern Europe, and Staikouras et al. (2008) banks in South Eastern Europe. Altunbaş and Marqués (2008) show that European bank mergers between 1984 and 1995 tended to improve performance. Bolt and Humphrey (2010) develop a bank competition efficiency frontier, while Chortareas et al. (2013) study the link between financial freedom and bank efficiency. Galema and Koetter (2016) find that European banks supervised by the Single Supervisory Mechanism, i.e. at the supranational level, were less efficient than banks supervised by the relevant national regulatory authority. A number of earlier European studies are cited in Berger and Humphrey (1997).

${ }^{4}$ More recent papers such as Komtolaimou et al. (2012), Kontolaimou (2014) and Korytowski (2018) suggest that significant differences in European bank efficiency persist.
} 
improvement over time. On the other hand, Mamatzakis et al. (2008) find evidence of convergence in the cost efficiency, but not in the profit efficiency, of new EU member state banks over the period 1998 to 2003. Brissimis et al. (2008) also explore the relationship between banking sector reform and the performance of banks in newly acceded EU countries over the period 1994 to 2005. They report that banking sector reform and greater competition raised bank efficiency, although the effect of reform on total factor productivity growth was significant only toward the end of the reform process. These and other pre-GFC developments in European banking are reviewed by Goddard and Molyneux (2007), who highlight the increased integration of European banking markets, and discuss the possible implications for (greater) systemic risk, (less effective) supervision, competition, bank strategies and technological change and efficiency.

European banks - especially banks in peripheral countries such as Greece, Ireland, Portugal and Spain - were severely affected by the GFC and related Eurozone sovereign debt crisis. Many European banks are still under-capitalized and saddled with large portfolios of non-performing loans. Fiordelisi et al. (2011) suggest that European banks with lagging pre-Crisis efficiency subsequently experienced higher risks and lower capital levels, which is consistent with a moral hazard explanation. Looking ahead, more efficient and productive European banks are much better placed to weather the legacy of the GFC and sovereign debt crisis, and crises such as the current Covid-19 pandemic.

Many studies of European bank efficiency suggest that GFC and Eurozone sovereign debt crisis negatively affected efficiency. Matousek et al. (2015) report an overall decline in EU-15 and Eurozone bank efficiency and convergence following the GFC and sovereign debt crisis. Lee and Huang (2017) find that the gradual upward trend in bank efficiency before 2007 was replaced by a downward trend over 2007 to 2010, arguing that managerial inability was the primary source of the inefficiencies. Although Asimakopoulos et al. (2018) suggest that the crises reversed the trend of gradual convergence in the efficiency of European core and periphery banks, noting that the core banks fared better than banks in the periphery. Korytowski (2018) also reports a significant deterioration in European bank efficiency during the crises.

Some exceptions to the general view that the GFC and sovereign debt crisis had a significant adverse impact on efficiency are Andries and Căpraru (2014), Andries and Ursu (2016), . Andries and Căpraru (2014) suggest that average cost and profit efficiency of EU-27 banks were relatively constant 
over the period 2004 to 2012, while Andries and Ursu (2016) argue the financial crisis had a significant and positive effect on both cost and profit efficiency. Both

\section{Measuring Bank Efficiency and Productivity Growth with Multiple Indicators}

In this paper, we augment a stochastic distance function measure of bank efficiency and productivity growth with multiple indicators of efficiency. Our multiple indicator approach is similar to, but more direct than, the multiple indicator-multiple cause (MIMIC) model of efficiency used by Chaudhuri et al. (2015), since technical efficiency is a scalar. Our approach is general, and may be used to augment cost, revenue and profit-based stochastic frontier models of bank efficiency. Augmenting stochastic frontier models with multiple indicators of efficiency take into account additional, relevant information, thereby generating more precise estimates of policy relevant issues such as returns to scale, technical inefficiency and productivity growth.

\section{(a) The Distance Function}

As banks produce multiple outputs using multiple inputs, we start from a general distance or transformation function $D(X, Y)=1$, where $X$ is a vector of inputs and $Y$ a vector of outputs. More formally, the output distance function is defined as $D(X, Y)=\min _{\theta}\{\theta>0$, such that $Y / \theta$ can be produced given $X$ \}, i.e. the distance function is the maximum expansion of output that can be produced with given inputs. $D(X, Y)$ is homogeneous of degree one in outputs. Moreover, $D(X, Y) \leq 1$, and equals unity if and only if the input-output combination is efficient. Additionally, the distance function is convex in outputs and concave in inputs. See Kumbhakar and Lovell (2000, chapter 2) for example.

Since the distance function is homogeneous of degree one in outputs, we can write $Y_{1}=$ $D\left(X, Y_{(-1)} / Y_{1}\right)$, where $Y_{(-1)}$ is the vector of outputs excluding $Y_{1}$. Taking logs of all variables we have $y_{1}=f\left(x, y_{(-1)}^{\dagger} ; \beta\right)$, where $y_{1}=\ln Y_{1}, y_{(-1)}^{\dagger}=\ln Y_{(-1)}-\ln Y_{1}, x=\ln X$, and $\beta$ is a parameter vector. Suppose, for example, Suppose, for example, there are two inputs and outputs, and the outputs $Y$ and inputs $X$ are related via a ${ }^{5}$ The function $f$ is in the form of a "production function": It is non-decreasing in inputs and non-increasing in outputs, and characterizes the production technology. To economize on

\footnotetext{
${ }^{5}$ Suppose, for example, there are two inputs and outputs, and the outputs $Y$ and inputs $X$ are related via a general transformation function $F_{1}(Y)=F_{2}(X)$, where $F_{1}$ is an output aggregator function and we can think of $F_{2}$ as the usual production function. One possibility, for example, is to have $Y_{1}^{\alpha} Y_{2}^{1-\alpha}=X_{1}^{\beta_{1}} X_{2}^{\beta_{2}}$, or in logs, $(1-\alpha) y_{1}+$ $\alpha y_{2}=\beta_{1} x_{1}+\beta_{2} x_{2}$ where lower case letters indicate logs and all parameters are positive. From this expression, it is clear that, if we choose $y_{1}$ as the dependent variable, we have $y_{1}=\beta_{1} x_{1}+\beta_{2} x_{2}-\alpha\left(y_{2}-y_{1}\right)$.
} 
notation, it is convenient to redefine $y=y_{1}$, and add $y_{(-1)}^{\dagger}$ and a time trend to the $x$ vector, with the understanding that $x$ now contains endogenous variables. The time trend captures technological change.

\section{(b) The Stochastic Frontier Distance Function}

Our distance function model for bank $i$ at time $t$ is standard:

$$
y_{i t}=f\left(x_{i t} ; \beta\right)+v_{i t}-u_{i t}=\beta_{0}+\beta_{1}^{\prime} x_{i t}+\frac{1}{2} x_{i t}^{\prime} B x_{i t}+v_{i t}-u_{i t}
$$

where $f()$ is a translog function (Christensen, Jorgenson and Lau, 1973) with parameter vector $\beta^{\prime}=$ $\left(\beta_{0}, \beta_{1}^{\prime}\right.$, vech $\left.(B)^{\prime}\right), v_{i t}$ is mean zero, symmetric random error term, and the non-negative $u_{i t}$ error term represents technical inefficiency. In our application, we have two inputs - loans and other earned assets (OEA) - and three inputs - labor, physical capital and deposits or funds. We denote log loans as $y$, so $x$ consists of the log of the (OEA/loans), the logs of the three inputs - labor, physical capital and deposits and a time trend. The data are described in more detail in the next Section.

$$
u_{i t} \sim N_{+}\left(\gamma^{\prime} z_{i t}, \sigma_{u}^{2}\right) \geq 0
$$

In line with the literature, we assume that $v_{i t}$ is a mean zero, normally distributed random error term, and technical inefficiency $u_{i t} \geq 0$ is a truncated normal error component. We allow technical inefficiency to depend on a vector $z_{i t}$ "causes" of inefficiency, with associated coefficient vector $\gamma$. Our $z$ variables are the bank's age, a time trend, input and output prices. ${ }^{6}$

To address endogeneity issues, we assume there is a vector of predetermined variables $w$, and a linear reduced form for $x$ :

$$
x_{i t}=\Pi w_{i t}+e_{i t}
$$

The reduced form allows for the endogeneity of the outputs as well as inputs, so it is very general in nature. We use a reduced form because the distance function is a representation of technology and, without additional behavioral assumptions, does not presume which variables are endogenous or predetermined. We allow the random error terms in the distance function and reduced form to be correlated.

$$
\left(v_{i t}, e_{i t}^{\prime}\right)^{\prime} \sim N(0, \Sigma)
$$

\footnotetext{
${ }^{6}$ Note that it is possible to include the vector of "inputs" $x$ in $z$, so that inefficiency $u$ is not assumed independent of the inputs and non-loan outputs. We leave this extension to further research.
} 
The $w$ variables in the reduced form (3) consist of current and lagged values of all input prices, lagged values of all inputs and outputs, their squares and interactions, dummy variables for all commercial, cooperative, savings, investment, and real-estate banks and their interactions with all the other variables.

\section{(c) Indicators of Inefficiency - MIMIC Equations}

The MIMIC-like system of equations assumes the presence of multiple indicators of technical inefficiency:

$$
\begin{aligned}
& w_{i t}=\lambda u_{i t}+\varepsilon_{i t} \\
& \varepsilon_{i t} \sim N\left(0, \Theta_{\varepsilon}\right),
\end{aligned}
$$

where $w$ is the vector of inefficiency indicators and $\lambda$ is the vector of factor loadings on the unobserved technical inefficiency. As in Chaudhuri et al. (2017), we include the return on assets (ROA) and return on equity (ROE) in our indicator vector $w$, but we augment them with the bank-specific Z-score, the ratio of equity to assets and the $\log$ volatility of ROA.

The idea is to jointly estimate the translog distance function, the reduced form and the MIMIC equations, i.e. equations (1) to (6), using the Bayesian methods of inference set out in the next Section. We refer to this as the full MIMIC-style model. We also consider three special cases of this model. The distance function on its own is model I. This model ignores the endogeneity of the input and other output variables in the distance function. Model II - the distance function and the reduced form - addresses the endogeneity issue by including a reduced form for $\mathrm{x}$. However, we argue that it ignores salient signals of technical efficiency. Model III, which consists of the MIMIC equations (5) and (6) on their own, is quite limited. It can generate estimates of technical inefficiency, but not estimates of returns to scale or productivity growth.

\section{Econometric Model}

In this Section, we set out the posterior distribution of our MIMIC-model model and show how to estimate it using Markov Chain Monte Carlo methods. Consider a sample of panel data $Y=$ $\left\{y_{i t}, x_{i t}, z_{i t}, w_{i t}, z_{0, i t}\right\}$ for $i=1, \ldots, N$ banks, and $t=1, \ldots, T$ time periods. Our model consists of the translog distance function $y_{i t}=f\left(x_{i t} ; \beta\right)+v_{i t}-u_{i t}$, the reduced form $x_{i t}=\Pi z_{i t}+e_{i t}$, and MIMIC

equations $w_{i t}=\lambda u_{i t}+\varepsilon_{i t}$, with random error terms $u_{i t} \mid z_{0, i t} \sim N_{+}\left(\gamma^{\prime} z_{0, i t}, \sigma_{u}^{2}\right), \quad\left(\begin{array}{c}v_{i t} \\ e_{i t}\end{array}\right) \sim N(0, \Sigma) \equiv$ 
$N\left(\left(\begin{array}{l}0 \\ 0\end{array}\right),\left(\begin{array}{cc}\sigma_{v}^{2} & \sigma_{v e} \\ \sigma_{e v} & \Sigma_{e e}\end{array}\right)\right)$ and $\varepsilon_{i t} \sim N\left(0, \Theta_{\varepsilon}\right)$ where all of the random error terms are independent of each other. The density function for a single observation is:

$$
\begin{array}{r}
f\left(y_{i t}, x_{i t}, w_{i t} \mid z_{i t}, z_{o, i t} ; \theta\right)= \\
\int_{0}^{\infty}(2 \pi)^{-(K+1) / 2}|\Sigma|^{-1 / 2} \exp \left\{\left(\begin{array}{c}
y_{i t}-f\left(x_{i t} ; \beta\right)+u_{i t} \\
x_{i t}-\Pi z_{i t}
\end{array}\right)^{\prime} \Sigma^{-1}\left(\begin{array}{c}
\left.y_{i t}-f\left(x_{i t} ; \beta\right)+u_{i t}\right) \\
x_{i t}-\Pi z_{i t}
\end{array}\right)\right\} \\
\times\left(2 \pi \sigma_{u}^{2}\right)^{-1 / 2} \exp \left\{-\frac{1}{2 \sigma_{u}^{2}}\left(u_{i t}-\gamma^{\prime} z_{o, i t}\right)^{2}\right\} \Phi\left(\frac{1}{\sigma_{u}}\left(u_{i t}-\gamma^{\prime} z_{o, i t}\right)\right)^{-1} \\
\times(2 \pi)^{-P / 2}\left|\Theta_{\varepsilon}\right|^{-1} \exp \left\{-\frac{1}{2}\left(w_{i t}-\lambda u_{i t}\right)^{\prime} \Theta_{\varepsilon}^{-1}\left(w_{i t}-\lambda u_{i t}\right)\right\} d u_{i t}
\end{array}
$$

where $\theta^{\prime}=\left(\beta^{\prime}, \gamma^{\prime}, \operatorname{vec}(\Pi)^{\prime}, \operatorname{vech}(\Sigma)^{\prime}, \operatorname{vech}\left(\Theta_{\varepsilon}\right)^{\prime}, \sigma_{u}\right)$ is the combined parameter vector, $K$ is the dimension of $\Sigma$, and $P$ is the number of indicators. By Bayes's theorem, the posterior distribution $p(\theta \mid Y) \propto L(\theta ; Y) \times p(\theta)$, where $L(\theta ; Y)=\prod_{i=1}^{N} \prod_{t=1}^{T} f\left(y_{i t}, x_{i t}, w_{i t} \mid z_{i t}, z_{o, i t} ; \theta\right)$ is the likelihood function and $p(\theta)$ is the prior. Unfortunately, the integral with respect to $u_{i t}$ in the likelihood is not available in closed form because of the presence of the normal distribution function $\Phi(\cdot)$ in the density of $y_{i t}$.

To overcome the difficulty with the integral, we consider the augmented posterior density $p\left(\theta,\left\{u_{i t}\right\} \mid Y\right)$, which is proportional to:

$$
\begin{aligned}
& |\Sigma|^{-\frac{N T}{2}} \exp \left\{-\frac{1}{2} \sum_{t} \sum_{i}\left(\begin{array}{c}
y_{i t}-f\left(x_{i t} ; \beta\right)+u_{i t} \\
x_{i t}-\Pi z_{i t}
\end{array}\right)^{\prime} \Sigma^{-1}\left(\begin{array}{c}
y_{i t}-f\left(x_{i t} ; \beta\right)+u_{i t} \\
x_{i t}-\Pi z_{i t}
\end{array}\right)\right\} \\
& \times \sigma_{u}^{-T N} \exp \left\{-\frac{1}{2 \sigma_{u}^{2}} \sum_{t} \sum_{i}\left(u_{i t}-\gamma^{\prime} z_{o, i t}\right)^{2}\right\} \prod_{t} \prod_{i} \Phi\left(\frac{1}{\sigma_{u}}\left(u_{i t}-\gamma^{\prime} z_{o, i t}\right)\right)^{-1} \\
& \times\left|\Theta_{\varepsilon}\right|^{-\frac{N T}{2}} \exp \left\{-\frac{1}{2} \sum_{t} \sum_{i}\left(w_{i t}-\lambda u_{i t}\right)^{\prime} \Theta_{\varepsilon}^{-1}\left(w_{i t}-\lambda u_{i t}\right)\right\} p(\theta)
\end{aligned}
$$

Before proceeding, it is useful to derive the posterior conditional distribution of technical inefficiency:

$$
p\left(u_{i t} \mid \theta, Y\right) \propto \exp \left\{-\frac{1}{2 \widetilde{\sigma}^{2}}\left(u_{i t}-\tilde{u}_{i t}\right)^{2}\right\} \Phi\left(\frac{1}{\sigma_{u}}\left(u_{i t}-\gamma^{\prime} z_{o, i t}\right)\right)^{-1}
$$

where $\tilde{u}_{i t}=\tilde{\sigma}^{2}\left(\sigma^{v v} r_{i t}+\frac{1}{\sigma_{u}} \gamma^{\prime} z_{0, i t}+\lambda^{\prime} \Theta_{\varepsilon}^{-1} w_{i t}\right), r_{i t}=y_{i t}-f\left(x_{i t} ; \beta\right)+\frac{\sigma^{e v}}{\sigma^{v v}}\left(x_{i t}-\Pi z_{i t}\right), \tilde{\sigma}^{2}=\left(\sigma^{v v}+\right.$ $\left.\sigma_{u}^{-2}+\lambda^{\prime} \Sigma_{\varepsilon}^{-1} \lambda\right)^{-1}$ and $\Sigma^{-1}=\left(\begin{array}{cc}\sigma_{v}^{2} & \sigma_{v e} \\ \sigma_{e v} & \Sigma_{e e}\end{array}\right)^{-1}=\left(\begin{array}{cc}\sigma^{v v} & \sigma^{v e} \\ \sigma^{e v} & \Sigma^{e e}\end{array}\right)$ 
Next we specify our priors, which we make as flat as possible relative to the likelihood. First, we assume $\Theta_{\varepsilon}$ is diagonal, so $\Theta_{\varepsilon}=\operatorname{diag}\left(\Theta_{\varepsilon, 1} \ldots \Theta_{\varepsilon, P}\right)$ where $\mathrm{P}$ is the number of MIMIC indicators. For the distance function parameters, our prior for the parameter vector $\beta$ is $\beta \sim N\left(0, h_{\beta}^{2} I\right)$. For the parameters of the $K \times M$ reduced form matrix $\Pi$, we assume that $\operatorname{vec}(\Pi) \sim N\left(0, h_{\Pi}^{2} I\right)$. Our priors for the other

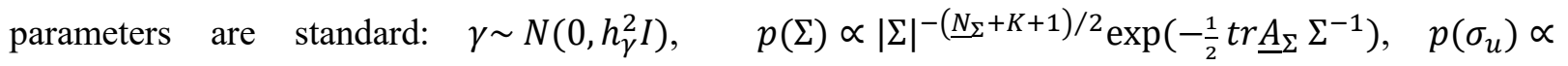
$\sigma_{u}^{-\left(\underline{N}_{u}+1\right)} \exp \left(-\frac{1}{2 \sigma_{u}^{2}} \underline{q}\right)$ and $p\left(\Theta_{\varepsilon}\right) \propto\left|\Theta_{\varepsilon}\right|^{-\left(\underline{N}_{\varepsilon}+K+1\right) / 2} \exp \left(-\frac{1}{2} \operatorname{tr} \underline{A}_{\varepsilon} \Theta_{\varepsilon}^{-1}\right)$. In the case of the MIMIC factor loadings, we use the prior $\lambda \sim N(0, I)$. Finally, we set $h_{\beta}=h_{\Pi}=h_{\gamma}=10^{4}, \underline{N_{\Sigma}}=\underline{N_{u}}=\underline{N_{\varepsilon}}=1, \underline{q}=$ $10^{-4}$ and $\underline{A_{\Sigma}}=\underline{A}_{\varepsilon}=10^{-4} I$.

We use a Markov chain Monte Carlo (MCMC) scheme to evaluate the augmented joint posterior in (A2). The MCMC cycles through random number generation from the following conditional posterior distributions:

Draw $\beta$ from the conditional posterior distribution $\beta \mid \gamma, \Pi, \Sigma_{\varepsilon}, \Sigma, \sigma_{u},\left\{u_{i t}\right\}, Y$.

Draw $\gamma$ from $\gamma \mid \beta, \Pi, \Theta_{\varepsilon}, \Sigma, \sigma_{u},\left\{u_{i t}\right\}, Y$.

Draw $\Pi$ from $\Pi \mid \beta, \gamma, \Theta_{\varepsilon}, \Sigma, \sigma_{u},\left\{u_{i t}\right\}, Y$.

Draw $\Sigma_{\varepsilon}$ from $\Theta_{\varepsilon} \mid \beta, \gamma, \Pi, \Sigma, \sigma_{u},\left\{u_{i t}\right\}, Y$.

Draw $\Sigma$ from $\Sigma \mid \beta, \gamma, \Pi, \Theta_{\varepsilon}, \sigma_{u},\left\{u_{i t}\right\}, Y$.

Draw $\sigma_{u}$ from $\sigma_{u} \mid \beta, \gamma, \Pi, \Theta_{\varepsilon}, \Sigma,\left\{u_{i t}\right\}, Y$.

Draw $u_{i t}$ from $u_{i t} \mid \beta, \gamma, \Pi, \Theta_{\varepsilon}, \Sigma, \sigma_{u}, Y$.

Steps (i), (iii), (iv) and (v) involve standard distributions, so random drawings are easily realized. For (ii), (vi) and (vii) the parameters also appear in the normal distribution function $\Phi(\cdot)$. Apart from this term, only standard distributions are involved so we use a simple Metropolis-Hastings independence algorithm to provide drawings from the posterior conditional distributions. For example, in step (ii) suppose we have a current draw $\gamma^{(s-1)}$. We draw a candidate from the "standard" part of the conditional posterior $\gamma^{*} \sim N_{Q}(\hat{\gamma}, V \gamma)$, where $\hat{\gamma}=h_{\gamma}^{2}\left(h_{\gamma}^{2} Z_{o}^{\prime} Z_{o}+\sigma_{u}^{2} I\right)^{-1} Z_{o}^{\prime} u, V \gamma=h_{\gamma}^{2} \sigma_{u}^{2}\left(h_{\gamma}^{2} Z_{o}^{\prime} Z_{o}+\sigma_{u}^{2} I\right)^{-1}, u$ is the $N T \times$ 1 vector consisting of all the $u_{i t}$ 's, and $Z_{o}$ is the $N T \times Q$ matrix consisting of the $z_{o, i t}$ 's. We then accept the candidate $\gamma^{*}$ with probability:

$$
\min _{i, j}\left\{1, \Phi\left(\left(u_{i t}-z_{o . i t}^{\prime} \gamma^{*}\right) / \sigma_{u}\right)^{-1} / \Phi\left(\left(u_{i t}-z_{o . i t}^{\prime} \gamma^{(s-1)}\right) / \sigma_{u}\right)^{-1}\right\}
$$


otherwise we set $\gamma^{(s)}=\gamma^{(s-1)}$. A similar construction is used to draw $\sigma_{u}$ in step (vi). The candidate is drawn from $\left(\left(u-Z_{o} \gamma\right)^{\prime}\left(u-Z_{o} \gamma\right)+\underline{q}\right) / \sigma_{u}^{2} \sim \chi^{2}\left(N T+\underline{N}_{u}\right)$. For step (vii) we draw a candidate $u_{i t}^{*} \sim N_{+}\left(\tilde{u}_{i t}, \sigma_{u}^{2}\right)$. Given the current draw $u_{i t}^{(s-1)}$, the candidate draw $u_{i t}^{*}$ is accepted with probability $\min _{i, j}\left\{1, \Phi\left(\left(u_{i t}^{*}-z_{o . i t}^{\prime} \gamma\right) / \sigma_{u}\right)^{-1} / \Phi\left(\left(u_{i t}^{(s-1)}-z_{o . i t}^{\prime} \gamma^{(s-1)}\right) / \sigma_{u}\right)^{-1}\right\}$, otherwise we set $u_{i t}^{(s)}=$ $u_{i t}^{(s-1)}$

\section{Data}

Our annual dataset includes commercial, cooperative and savings banks in the EU-15 countries that are listed in the Bankscope database over the period 2008-2015, a period that includes the GFC and Eurozone sovereign debt crisis. The 15 countries are Austria, Belgium, Denmark, Finland, France, Germany, Greece, Ireland, Italy, Luxembourg, Netherlands, Portugal, Spain, Sweden and the United Kingdom. We restrict our analysis to credit institutions that report positive equity capital. After reviewing the data for reporting errors and other inconsistencies, we obtain an unbalanced panel dataset of 18,813 observations, which includes 2,861 different banks.

For the estimation of bank efficiency, we employ the Sealey and Lindley (1977) intermediation approach for the definition of bank inputs and outputs. Sealey and Lindley assume that banks collect funds, and use labor and physical capital to transform the funds into loans and other earning assets. In particular, we specify three inputs - labor, physical capital and financial capital - and two outputs - loans and other earning assets (government securities, bonds, equity investments, CDs, T-bills, equity investment etc.). The input prices are calculated as follows: the price of labor equals the ratio of personnel expenses to total assets; the price of physical capital equals the ratio of other administrative expenses to fixed assets, and the price of deposits (financial capital) equals total interest expenses divided by total interest bearing borrowed funds. The $Z$ score distance-to-default measure of risk taking for bank $i$ at time $t$ is calculated as $Z_{i t}=\left(R O A_{i t}+\right.$ Equity $_{i t} /$ Assets $\left._{i t}\right) / \sigma_{i t}$, where $\sigma_{i t}$ it is the three-year standard deviation of $R O A_{i t}$.

\section{-- Table 1 -}

Table 1 provides some descriptive statistics for our main variables. The statistics are presented for each country and for the overall EU-15 sample. We observe considerable variation across countries in relation to costs, revenues, as well as bank inputs and outputs. Spain and Sweden have the lowest average 
cost-to-assets ratio (3.5\%), while Denmark stands at the other end of the spectrum (5\%). In addition, Denmark has the highest revenue-to-assets ratio (6.6\%), while Finland and Ireland have the lowest. In the vast majority of EU-15 countries, loans comprise the largest share of the banks' balance sheets - the exceptions being Luxembourg, Belgium and the UK. The price of labor ranges from $0.6 \%$ in Ireland to $1.8 \%$ in Denmark. Moreover, there is considerable variation with respect to the price of physical capital, which ranges from $48.7 \%$ in Spain to $286.8 \%$ in Luxembourg, while the price of deposits ranges from $1.6 \%$ in Sweden to $4.3 \%$ in the Netherlands. In addition, banks' average equity-to-assets ratio ranges from $6.5 \%$ in Germany and Ireland to $14.2 \%$ in Sweden.

\section{Empirical Results}

In this section, we present and discuss the results from the full MIMIC model, as well as the three nested models - models I, II and III. Model I is the distance function, with an allowance for technical inefficiency, and may be used to generate estimates of returns to scale, technical change and productivity growth. Model II improves on model I by adding the reduced form to account for endogeneity of the RHS variables in the distance function. Model III, which consists of the MIMIC indicator equations with an allowance for technical inefficiency, is not nested within models I and II, and is silent about many important aspects of bank efficiency such as returns to scale, technical change and productivity growth.

We run our Markov Chain Monte Carlo (MCMC) procedure for 150,000 iterations, discarding the first 50,000 to mitigate possible start-up effects. Convergence is assessed by drawing 10 different sets of starting values from the prior, and rerunning the MCMC. For each set of starting points, we retain 50,000 iterations after discarding the first 10,000 iterations. The resulting posterior means and standard deviations are almost identical to those reported in the Tables.

-- Table 2 --

\section{(a) Full Sample Results}

In Table 2 we report the posterior means and standard deviations for the basic elasticities and other parameters of interest from the full MIMIC model. The change in efficiency is defined as $E C_{i t}=$ $r_{i t}-r_{i t-1}$, where $r_{i t}=e^{-\widetilde{u}_{i t}}$ and $\tilde{u}_{i t}$ is our measure of technical inefficiency. Technical change is $T C_{i t}=\partial f\left(x_{i t} ; \beta\right) / \partial t$, and productivity growth is the sum of the change in technical efficiency and productivity growth, $P G_{i t}=E C_{i t}+T C_{i t}$. In Figure 1 we show the marginal posterior densities with respect to all three input elasticities (labor, capital and deposits), as well as the elasticity with respect to 
other earned assets (OEA), the second output. ${ }^{7}$ The marginal posterior density of returns to scale (RTS) is shown in Figure 2, and in Figure 3 we plot the marginal posterior densities of technical inefficiency, technical change, efficiency change and productivity growth.

The posterior means of the bank specific inputs - capital, labor and deposits - are all positive in Table 2, confirming that an increase in inputs increases bank lending. The magnitude of the elasticity of bank loans with respect to deposits is the largest at 0.412, highlighting the important role of deposits in funding lending. The large positive deposit and negative OEA elasticities are in line with existing results in the literature (e.g., Chaffai et al., 2001; Casu et al., 2004; Koutsomanoli et al., 2009; Delis et al., 2011). As expected, Figure 1 shows that the marginal posterior densities from the full MIMIC model are much tighter than the densities from models I and II.

-- Figures 1 and 2 --

The three input elasticities - labor 0.344, capital 0.232 and deposits 0.4110 - in Table 2 suggest that returns to scale are close to unity, and indeed our estimations show constant returns to scale. Figure 2 shows that the marginal posterior density of the returns to scale parameter is tightly centered on one. The average technical inefficiency of the EU-15 banks is quite substantial - almost $15 \%$ (the posterior mean is 0.148 ). The posterior density of technical inefficiency $\tilde{u}_{i t}$ is slightly bimodel with a long right hand side tail (Figure 3, top left panel).

-- Figure 3 --

his is the first study to reveal the whole density function of productivity growth for EU-15 banks over this period, clearly showing that productivity growth was negative for most banks in the sample. We estimate that average productivity growth was $-0.0168(-1.68 \%)$ per annum for all banks. It is interesting that the estimates of both components of productivity growth - technical change and efficiency change - are negative at -0.0093 and -0.0075 respectively, . The posterior densities of the change in efficiency, technical change and productivity growth are also shown in Figure 3.

Technical change (top right panel of Figure 3) clearly has a detrimental effect on productivity growth since, in the full MIMIC model, it is negative across almost all of the spectrum of the density function. The density of efficiency change (bottom left panel) is almost symmetrical, with positive

\footnotetext{
${ }^{7}$ The posterior densities are averaged across MCMC draws to take parameter uncertainty into account.
} 
efficiency change values for about one-third of the banks. The density of productivity growth (bottom right panel) is bimodal, and skewed to the left towards negative values. Technical change clearly has a detrimental effect on productivity growth since, in the full MIMIC model, it is also negative across almost the whole domain of the density function. It is striking that, for the vast majority of the banks in our sample, technology regress drove down productivity growth. The policy implication is that the EU banking industry would benefit in terms of productivity and efficiency from innovation.

\section{(b) Subsample Results - Large and Small Banks, Periphery and Core Banks}

We now consider the estimated parameters of interest for larger and smaller banks, and for banks in the EU-15 "Core" and "Periphery" (Greece, Ireland, Italy, Portugal and Spain) set out in Table $3 .^{8}$ The full MIMIC model was estimated on each subsample, i.e. allowing for full parameter heterogeneity, so the results for the different sub-samples should not be compared with the all bank results in Table 2. Estimated returns to scale are close to one, except for smaller banks where returns are increasing. Larger banks and banks in the rest of the EU-15 rely more on other earned assets. In line with expectations, smaller banks and banks in Greece, Ireland, Italy, Spain and Portugal tend to be more inefficient. The productivity growth estimates suggest that productivity regress is greater in smaller banks than in larger banks. On average, the components of productivity growth are positive for banks in the "core" and negative for banks in Greece, Ireland, Italy, Spain and Portugal.

-- Table 3 --

\section{(c) Loadings on Technical Inefficiency Indicators}

We now present some additional results for our modified MIMIC model. In the top panel of the Table 4, we present the posterior means and standard deviations of the technical inefficiency loadings for our five indicators of efficiency - ROA, ROE, the equity-to-total assets ratio, the Z-score measure of distance to default, and the log of the volatility of ROA. Results are presented for the five major bank specializations in our sample, i.e. commercial, cooperative, savings, investment and real estate banks. Although the estimated loadings vary by bank specialization, all of the factor loadings, apart from that on volatility, are negative in line with our priors. The loadings suggest that, in our sample of EU-15 banks,

\footnotetext{
${ }^{8}$ We classify large banks as banks with total assets above the median.
} 
greater technical efficiency is associated with higher profitability, lower leverage, a lower probability of default and lower return volatility.

-- Table 4 --

\section{(d) Drivers of Inefficiency}

We turn to the observable drivers of technical inefficiency in the lower panel of Table 4. Rather than reporting the posterior means and standard deviations of the $\gamma$ parameters in our technical inefficiency equation, $u_{i t} \sim N_{+}\left(\gamma^{\prime} z_{i t}, \sigma_{u}^{2}\right)$, we report a subset of the estimated marginal effects $\partial \ln \left(u_{i t} \mid z_{i t}, \gamma, \sigma_{u}^{2}\right) / \partial z_{i t}$ averaged across the sample. In line with the model and our priors, the marginal inefficiency effects for the three input prices (labor, physical capital and deposits) are positive, whereas the marginal effects for the two output prices are negative. The bank age and technology trend marginal inefficiency effects are negative. The results shed new light on previous research (e.g. Chaffai et al., 2001; Casu et al., 2004; Koutsomanoli et al., 2009; Delis et al., 2011), suggesting that diversifying by producing other earning assets and gaining experience, as well as investing in new technology, may enhance banking technical efficiency.

\section{Further Model Checks}

We estimated the full MIMIC model and three nested models. Although we presented some results from the nested models I, II and II in the Figures, we focused on the full MIMIC model results. Since the nested and full MIMIC model results are materially different from each other, we believe a formal comparison of the "fit" of the different models is warranted. We check the fit of the models using Bayes factors and predictive densities. In addition, we check the sensitivity of our results to the omission of some of the MIMIM indicators.

\section{-- Figure 4 --}

\section{(a) Bayes Factors for Nested Models}

Given any two models, the Bayes factor in favor of model 1 and against model 2 is $B F_{1: 2}=$ $M_{1}(Y) / M_{2}(Y)$, where $M_{1}(Y)$ and $M_{2}(Y)$ are the marginal likelihoods of the two models with data $Y$. The marginal likelihood of a model with the d-dimensional parameter vector $\theta$, likelihood $L(\theta ; Y)$ and prior $p(\theta)$ is $M(Y)=\int L(\theta ; Y) p(\theta) d \theta$. Rearranging the marginal likelihood identity $p(\theta \mid Y)=$ 
$L(\theta ; Y) p(\theta) M(Y)$, we see that $M(Y)=L(\theta ; Y) p(\theta) / p(\theta \mid Y)$. This expression holds identically for all $\theta$ in the relevant parameter space (Chib, 1995), and is readily approximated. The denominator is approximately multivariate normal, which is always true in large samples. The mean of the normal distribution, $\bar{\theta}$, can be obtained as the posterior mean of $S$ MCMC draws, and the same is true for the posterior covariance matrix, $\bar{V}=\frac{1}{S} \sum_{s=1}^{S}\left(\theta^{(s)}-\bar{\theta}\right)\left(\theta^{(s)}-\bar{\theta}\right)^{\prime}$. Hence, the approximation to the $\log$ of the marginal likelihood may be computed as (Perrakis et al., 2015):

$$
\ln M(Y) \approx \ln L(\bar{\theta} ; Y)+\ln p(\bar{\theta})+\frac{d}{2} \ln (2 \pi)+\frac{1}{2} \ln |\bar{V}|
$$

Using this approximation to the marginal likelihood, we compare our Full MIMIC model with models I, II and III on different sub-samples of the data. The different sub-samples are generated by randomly omitting a block consisting of 20 observations. We do this for 1,000 different sub-samples. To avoid repeated MCMC, we use the original MCMC sample $\left\{\theta^{(s)}, s=1, \ldots, S\right\}$ from the full posterior $p(\theta \mid Y)$. To approximate samples from the posterior $p\left(\theta \mid Y_{(m)}\right)$ in the $m^{\prime}$ th sub-sample $(m=1, \ldots, M)$, we use sampling-importance-resampling (Rubin, 1987), where the size of MCMC is reduced to $10 \%$ of the original sample.

The densities of the Bayes factors are presented in Figure 4, which clearly shows that all of the Bayes factors favor the full MIMIC model. A Bayes factor $B F_{1: 2}>1$ is evidence in favor of model 1 relative to model 2. However, the strength of evidence differs by the magnitude of the Bayes factor. According to Kass and Raftery (1995), Bayes factors between 20 and 150 indicate "strong" evidence and a Bayes factor is excess of 150 indicate "very strong" evidence. By this categorization, we clearly have "very strong" evidence in favor of the full MIMIC model.

\section{(b) Predictive Densities}

The dependent variables can be predicted and compared to their actual values over different subsamples. Different models clearly imply different predictive densities, $p\left(y^{o} \mid Y_{(m)}\right)$, where $Y_{(m)}$ is a subsample of the data used for inference and $y^{o}$ are the data to be predicted. The superscript "o" stands for outcome. To compare different models we use the log predictive score (LPS) of a given model, which is defined as follows (Geweke and Amisano, 2011):

$$
L P S=\ln p\left(y^{o} \mid Y_{(m)}\right)=\ln \int p\left(y^{o}, \theta \mid Y_{(m)}\right) d \theta=\int p\left(y^{o} \mid \theta, Y_{(m)}\right) p\left(\theta \mid Y_{(m)}\right) d \theta
$$


Clearly, we should select the model with the highest LPS. Given a set of MCMC draws, $\left\{\theta^{(s)}, s=\right.$ $1, \ldots, S\}$ from $p\left(\theta \mid Y_{(m)}\right)$, then $L P S \approx \ln \left(\frac{1}{s} \sum_{s} p\left(y^{o} \mid \theta^{(s)}, Y_{(m)}\right)\right)$ where $p\left(y^{o} \mid \theta^{(s)}, Y_{(m)}\right)$ is a product of densities under the assumption that $y^{o}$ has components that are stochastically independent. When $p\left(y^{o} \mid \theta^{(s)}, Y_{(m)}\right)=\prod_{j=1}^{J} p\left(y_{j}^{o} \mid \theta^{(s)}, Y_{(m)}\right)$, with $J=20$ in our case, each density can be closely approximated using a kernel density estimator based on the draws $y_{j}^{o,(s)} \sim y_{j}^{o} \mid \theta^{(s)}, Y_{(m)}$ for $s=1, \ldots, S$. This approximation can always be improved upon, as it depends on the number of draws $S$, rather than the sample size or the size of the sub-sample.

\section{-- Figure 5 -}

For model comparisons, we consider the difference in the log predictive densities: $\triangle L P S=$ $L P S_{1}-L P S_{2}$ where $L P S_{1}$ and $L P S_{2}$ are the log predictive scores of the two models, 1 and 2 , under consideration. The density of $\triangle L P S$ arising from the different sub-samples is shown in Figure 5. The difference of LPS is largest relative to model III, which is expected as this model includes only indicator variables. The full MIMIC model has an LPS that differs on average from models I and II by approximately $\exp (5.5)=245$. To summarize, in terms of Bayes factors and predictive densities, our novel MIMIC model dominates the nested stochastic frontier models (models I and II) as well as the standard MIMIC model (model III).

\section{-- Table 5 -}

\section{(c) Sensitivity of Parameter Estimates to Choice of Indicators}

To examine the sensitivity of our results to the choice of five MIMIC indicators, we re-ran our models omitting one of the indicators in turn and retaining the best models in terms of Bayes factors. The results in Table 4 are reported as percentage differences from the baseline specification in Table 2 . Generally, we find some sensitivity to the exclusion of an indicator, particularly when we omit the Zscore or volatility indicators. If the Z-score is omitted, the posterior mean suggests that returns to scale are decreasing on average, and technical inefficiency is about one-tenth lower. Overall, the estimates of productivity growth, efficiency and technical change, are robust to dropping one of the indicators. This is reassuring, since there are good a priori reasons to expect the estimates of technical inefficiency and productivity growth to be relatively invariant to the exclusion of key indicators of latent "performance". 
-- Figure 6 -

An interesting question is whether we should omit any of the 30 combination of the five indicators variables. We take the full model as the benchmark, and compute Bayes factors for the 30 different models relative to the benchmark. The resulting Bayes factors are plotted in Figure 6, where the factors are arranged in increasing order. Clearly, there is no support for any version of the MIMIC-style model with fewer than five indicators since the highest Bayes factor in favor of them is tiny - less than $10^{-4}$.

\section{Summary and Conclusions}

In this paper, we develop a new multiple-indicator multiple-cause style model of bank technical efficiency and productivity growth by augmenting a stochastic distance function with additional performance indicators, including measures of profitability, capital, risk and volatility. The model combines structural and non-structural approaches to measuring efficiency, and takes account of the endogenous risk-return tradeoff. Our novel MIMIC-style model may be estimated using standard Bayesian MCMC methods. It may be used with cost, revenue and profit stochastic frontier models, so both allocative and technical efficiency can be examined. It also generates more precise estimates of policy-relevant parameters, including returns to scale, technical inefficiency and productivity growth

We use the model to study the underlying bank performance of European banks. We find considerable variation in the performance of EU-15 banks over the period 2008 to 2015. For the vast majority of banks, productivity growth - the sum of efficiency and technical changes - is negative, implying that the banking industry would benefit from innovation. We show that greater technical efficiency is associated with higher profitability, lower leverage, a lower probability of default and lower return volatility. In line with expectations, smaller banks and banks in the "Periphery" (Greece, Ireland, Italy, Spain and Portugal) tend to be more inefficient. The productivity growth estimates suggest that productivity regress is greater in smaller banks than in larger banks. Finally, the change in efficiency and technical progress components of productivity growth are on average negative for banks in the "Periphery" and positive for banks in the rest of the EU-15.

\section{References}

Albert, J.H., Chib, S., 1993, Bayesian analysis of binary and polychotomous response data, Journal of the American Statistical Association, 88:422, 669-79. https://doi.org/10.1080/01621459.1993.10476321 
Ali, A.I., Gstach, D., 2000, The impact of deregulation during 1990-1997 on banking in Austria, Empirica, 27(3), 265-81. https://doi.org/10.1023/A:1007164501521

Altunbaş Y., Gardener E.P.M., Moore, B., 2001, Efficiency in European banking, European Economic Review, 45(10), 1931- 55. https://doi.org/10.1016/s0014-2921(00)00091-x

Altunbaş, Y., Marqués, D., 2008, Mergers and acquisitions and bank performance in Europe: The role of strategic similarities, Journal of Economics and Business, 60(3), 204-22.

https://doi.org/10.1016/j.jeconbus.2007.02.003

Andries, A., Căpraru, B., 2014, The nexus between competition and efficiency: the European banking industries experience, International Business Review, 23, 566-79.

https://doi.org/10.1016/j.ibusrev.2013.09.004

Andries, A., Ursu, S., 2016, Financial crisis and bank efficiency: Am empirical study of European banks, Economic Research-Ekonomska Istraživanja, 29(1), 485-97.

https://doi.org/10.1080/1331677x.2016.1175725

Asimakopoulos, G., Chortareas, G., Xanthopoulos, M., 2018, The Eurozone financial crisis and bank efficiency asymmetries: Peripheral versus core economies, The Journal of Economic Asymmetries, 18, e00099. https://doi.org/10.1016/j.jeca.2018.e00099

Avisoa, E., 2016, European banks' technical efficiency and performance: Do business models matter? The case of European co-operatives banks, Débats économiques et financiers, 25, Banque de France.

Barros, C.P., Peypoch, N., Williams, J., 2010, A note on productivity change in European cooperative banks: The Luenberger indicator approach, International Review of Applied Economics, 24(2), 137-47. https://doi.org/10.1080/02692171003590047

Baselga-Pascual, L., Trujillo-Ponce, A., Cardone-Riportella, C., 2015, Factors influencing bank risk in Europe: Evidence from the financial crisis, The North American Journal of Economics and Finance, 34, 138-66. https://doi.org/10.1016/j.najef.2015.08.004

Battese, G.E., Heshmati, A., Hjalmarsson, L., 2000, Efficiency of labour use in the Swedish banking industry: A stochastic frontier approach, Empirical Economics, 25, 623-40.

https://doi.org/10.1007/s001810000037

Berger, A.N., Humphrey, D.B., 1997, Efficiency of financial institutions: International survey and directions for further research, European Journal of Operational Research, 98(2), 175-212. https://doi.org/10.1016/S0377-2217(96)00342-6.

Berger, A.N., Dai, Q., Ongena, S., Smith, D.C., 2003, To what extent will the banking industry be globalized? A study of bank nationality and reach in 20 European nations, Journal of Banking \& Finance, 27(3), 383-415. https://doi.org/10.1016/s0378-4266(02)00386-2

Bolt, W., Humphrey, D., 2010, Bank competition efficiency in Europe: A frontier approach, Journal of Banking \& Finance, 34(8), 1808-17. https://doi.org/10.1016/j.jbankfin.2009.09.019 
Bos, J.W.B., Schmiedel, H., 2007, Is there a single frontier in a single European banking market? Journal of Banking \& Finance, 31, 2081-102. https://doi.org/10.1016/j.jbankfin.2006.12.004

Boucinha, M., Ribeiro, N., Weyman-Jones, T., 2013, An assessment of Portuguese banks' efficiency and productivity towards Euro area participation, Journal of Productivity Analysis, 39(2), 177-90. https://doi.org/10.1007/s11123-012-0310-2

Brissimis, S., Delis, M., Papanikolaou, N. (2008), Exploring the nexus between banking sector reform and performance: Evidence from newly acceded EU countries, Journal of Banking \& Finance, 32(12), 2674-83. https://doi.org/10.1016/j.jbankfin.2008.07.002

Canhoto, A., Dermine, J. ,2003, A note on banking efficiency in Portugal, new vs. old banks, Journal of Banking \& Finance, 27(11), 2087-98. https://doi.org/10.1016/S0378-4266(02)00316-3

Casu, B., Girardone, C., 2010, Integration and efficiency convergence in EU banking markets, Omega, 38, 260-7. https://doi.org/10.1016/j.omega.2009.08.004

Casu, B., Girardone, C., Ferrari, A., Wilson, J.O.S., 2016, Integration, productivity and technological spillovers: Evidence for Eurozone banking industries, European Journal of Operational Research, 255(3), 971-83. https://doi.org/10.1016/j.ejor.2016.06.007

Casu, B., Girardone, C., Molyneux, P., 2004, Productivity change in European banking: A comparison of parametric and non-parametric approaches, Journal of Banking \& Finance, 28(10), 2521-40. https://doi.org/10.1016/j.jbankfin.2003.10.014

Casu, B., Molyneux, P., 2003, A comparative study of efficiency in European banking, Applied Economics, 35, 1865-76. https://doi.org/10.1080/0003684032000158109

Chib, S., Greenberg, E., 1998, Analysis of multivariate probit models, Biometrika, 85(2), 347-61. https://doi.org/10.1093/biomet/85.2.347

Chaffai, M.E., Dietsch, M., Lozano-Vivas, A., 2001, Technological and environmental differences in the European banking industries, Journal of Financial Services Research, 19(2-3), 147-62.

Chaudhuri, K., Kumbhakar, S.C., Sundaram, L., 2016, Estimation of firm performance from a MIMIC model, European Journal of Operational Research, 255 (1), 298-307.

https://doi.org/10.1016/j.ejor.2016.05.005

Christensen, L., Jorgenson, D., Lau, L., 1973, Transcendental logarithmic production frontiers, The Review of Economics and Statistics, 55(1), 28-45. https://doi.org/10.2307/1927992

Chortareas, G.E., Girardone, C., Ventouri, A., 2013, Financial freedom and bank efficiency: Evidence from the European Union, Journal of Banking \& Finance, 37, 1223-31.

https://doi.org/10.1016/j.jbankfin.2012.11.015

Degl'Innocenti, M., Kourtzidis, S.A., Sevic, Z., Tzeremes, N.G., 2017, Bank productivity growth and convergence in the European Union during the financial crisis, Journal of Banking \& Finance, 75, 184 99. https://doi.org/10.1016/j.jbankfin.2016.11.016 
Delis, M. Iosifidi, M., Tsionas, M., 2017, Endogenous bank risk and efficiency, European Journal of Operational Research, 260(1), 376-87. https://doi.org/10.1016/j.ejor.2016.12.024.

Delis, M.D., Molyneux, P., Pasiouras, F., 2011, Regulations and productivity growth in banking: Evidence from transition economies, Journal of Money, Credit and Banking, 43(4), 735-64. https://doi.org/10.1111/j.1538-4616.2011.00393.x

Demirgüç-Kunt, A., Huizinga, H. (2010), Bank activity and funding strategies: The impact on risk and returns, Journal of Financial Economics, 98(3), 626-50. https://doi.org/10.1016/j.jfineco.2010.06.004

Dietsch, M., Lozano-Vivas, A., 2000, How the environment determines banking efficiency: A comparison between French and Spanish industries, Journal of Banking \& Finance, 24(6), 985-1004. https://doi.org/10.1016/S0378-4266(99)00115-6

Epure, M., Kerstens, K., Prior, D., 2011, Bank productivity and performance groups: A decomposition approach based upon the Luenberger productivity indicator, European Journal of Operational Research, 211(3), 630-41. https://doi.org/10.1016/j.ejor.2011.01.041

Fiordelisi, F., Marques-Ibanez, D., Molyneux, P., 2011, Efficiency and risk in European banking, Journal of Banking \& Finance, 35(5), 1315-26. https://doi.org/10.1016/j.jbankfin.2010.10.005

Fries, S., Taci, A., 2005, Cost efficiency of banks in transition: Evidence from 289 banks in 15 postcommunist countries, Journal of Banking \& Finance, 29(1), 55-81.

https://doi.org/10.1016/j.jbankfin.2004.06.016

Galema, R., Koetter, M., 2016, European bank efficiency and performance: The effects of supranational versus national bank supervision," in Beck. T., Casu, B. (eds.), The Palgrave Handbook of European Banking, chapter 11, Palgrave Macmillan: London, 257-92. https://doi.org/10.1057/978-1-137-52144-6

Geweke, J., Amisano, G., 2011, Optimal prediction pools, Journal of Econometrics, 164(1), 130-41. https://doi.org/10.1016/j.jeconom.2011.02.017

Goddard, J.A., Molyneux, P., Wilson, J.O.S., Tavakoli, M., 2007, European banking: An overview, Journal of Banking \& Finance, 31, 1911-35. https://doi.org/10.1016/0378-4266(94)00034-4

Goddard, J.A., Molyneux, P., Wilson, J.O.S., 2019, Banking in Europe: Integration, reform, and the road to a banking union, in Berger, A.N., Molyneux, P, Wilson, J.O.S. (eds.), The Oxford Handbook of Banking (3rd edn.), chapter 32, Oxford University Press: Oxford.

https://doi.org/oxfordhb/9780198824633.013.32

Girardone, C., Molyneux, P., Gardener, E.P.M., 2004, Analysing the determinants of bank efficiency: The case of Italian banks, Applied Economics, 36(3), 215-27.

https://doi.org/10.1080/0003684042000175334

Girardone, C., Nankervis, J.C., Velentza, E., 2009, Efficiency, ownership and financial structure in European banking, Managerial Finance, 35, 227-245. https://doi.org/10.1108/03074350910931753 
Hughes, J.P., Mester, L.J., 2013, Who said large banks don't experience scale economies? Evidence from a risk-return-driven cost function, Journal of Financial Intermediation, 22(4), 559-85.

https://doi.org/10.1016/j.jfi.2013.06.004

Hughes, J.P., Mester, L.J., 2019, The performance of financial institutions: Modelling, evidence and some policy implication, in Berger, A.N., Molyneux, P., Wilson, J.O.S. (eds), The Oxford Handbook of Banking (3rd edn), chapter 8, Oxford University Press: Oxford.

https://doi.org/oxfordhb/9780198824633.013.32

Jöreskog, K.G. and Goldberger, A.S., 1975, Estimation of a model with multiple indicators and multiple causes of a single latent variable, Journal of the American Statistical Association, 70, 631-39. https://doi.org/10.1080/01621459.1975.10482485

Kasman, A., Yildirim, C., 2006, Cost and profit efficiencies in transition banking: the case of new EU members, Applied Economics, 38, 1079-90. https://doi.org/10.1080/00036840600639022

Köhler, M., 2015, Which banks are more risky? The impact of business model on bank stability, Journal of Financial Stability, 16, 195-212. https://doi.org/10.1016/j.jfs.2014.02.005

Kass, R.E., Raftery, A.E., 1995, Bayes factors, Journal of the American Statistical Association, 90(430), 773-95. https://doi.org/10.1080/01621459.1995.10476572

Kontolaimou, A., 2014, An efficiency analysis of European banks considering hierarchical technologies, Applied Economics Letters, 21(10), 629-96. https://doi.org/10.1080/13504851.2014.884693

Kontolaimou, A., Kounetas, K., Mourtos, I., Tsekouras, K., 2012, Technology gaps in European banking: Put the blame on inputs or outputs?, Economic Modelling, 29(5), 1798-1808. https://doi.org/10.1016/j.econmod.2012.05.028

Kontolaimou, A, Tsekouras, K. 2010, Are cooperatives the weakest link in European banking? A nonparametric meta-frontier approach, Journal of Banking \& Finance, 34(8), 1946-57.

https://doi.org/10.1016/j.jbankfin.2010.01.003

Koutsomanoli-Filippaki, A., Mamatzakis, E., 2009, Performance and Merton-type default risk of listed banks in the EU: A panel VAR approach, Journal of Banking \& Finance, 33, 2050-61.

https://doi.org/10.1016/j.jbankfin.2009.05.009

Koutsomanoli-Filippaki, A., Margaritis, D., Staikouras, C., 2009, Efficiency and productivity growth in the banking industry of Central and Eastern Europe, Journal of Banking \& Finance, 333(3), 557-67. https://doi.org/10.1016/j.jbankfin.2008.09.009

Korytowski, M., 2018, Bank's profitability determinants in post-crisis European Union, Journal of Finance and Banking Studies, 7(1) 1-12. https://doi.org/10.20525/ijfbs.v7i1.847

Kuc M., 2017, Cost efficiency of European cooperative banks: Are small institutions predestined to fail?, in Procházka, D. (ed.), New Trends in Finance and Accounting, Springer Proceedings in Business and Economics, Springer, Cham. https://doi.org/10.1007/978-3-319-49559-0_10 
Kumbhakar, S.C., Lozano-Vivas, A., 2005, Deregulation and productivity: The case of Spanish banks, Journal of Regulatory Economics, 27(3), 331-51. https://doi.org/10.1007/s11149-005-6627-2

Kumbhakar, S.C., Lovell, C.A.K., 2000, Stochastic Frontier Analysis, Cambridge University Press, New York.

Kumbhakar, S.C., Lozano-Vivas, A., Lovell, C.A.K., Hasan, I., 2001, The effects of deregulation on the performance of financial institutions: The case of Spanish savings banks, Journal of Money, Credit and Banking, 33(1), 101-20. https://doi.org/10.2307/2673874

Laeven, L., Levine, R., 2007, Is there a diversification discount in financial conglomerates, Journal of Financial Economics, 85(2), 331-67. https://doi.org/10.1016/j.jfineco.2005.06.001

Lee, C.-C., Huang, T.-H., 2017, Cost efficiency and technological gap in Western European banks: A stochastic meta-frontier analysis, International Review of Economics and Finance, 48, 161-78. https://doi.org/10.1016/j.iref.2016.12.003

Lensink, R., Meesters, A., Naaborg, I., 2008, Bank efficiency and foreign ownership: Do good Institutions matter? Journal of Banking and Finance, 32, 834-44.

https://doi.org/10.1016/j.jbankfin.2007.06.001

Lozano-Vivas, A., 1998, Efficiency and technical change for Spanish banks, Applied Financial Economics, 8, 289-300. https://doi.org/10.1080/096031098333041

Lozano-Vivas, A., Pastor, J.T., Pastor, J.M., 2002, An efficiency comparison of European banking systems operating under different environmental conditions, Journal of Productivity Analysis, 18, 5977. https://doi.org/10.1023/A:1015704510270

Mamatzakis, E., Staikouras, C., Koutsomanoli-Filippaki, A., 2008, Bank efficiency in the new European Union member states: Is there convergence?, International Review of Financial Analysis, 17, 1156-72. https://doi.org/10.1016/j.irfa.2007.11.001

Matousek, R., Rughoo, A., Sarantis, N., Assaf, A.G., 2015, Bank performance and convergence during the financial crisis: Evidence from the 'old' European Union and Eurozone, Journal of Banking \& Finance, 52, 208-16. https://doi.org/10.1016/j.jbankfin.2014.08.012

Maudos, J. Pastor, J., Perez, F., Quesada, J., 2002, Cost and profit efficiency in European banks, Journal of International Financial Markets, Institutions and Money, 12, 33-58.

https://doi.org/10.1016/s1042-4431(01)00051-8

Pasiouras, F., Kosmidou, K., 2007, Factors influencing the profitability of domestic and foreign commercial banks in the European Union, Research in International Business and Finance, 21(2), 22237. https://doi.org/10.1016/j.ribaf.2006.03.007

Perrakis, K., Ntzoufras, I., Tsionas, M., 2015, On the use of marginal posteriors in marginal likelihood estimation via importance sampling, Computational Statistics and Data Analysis, 77, 54-69.

https://doi.org/10.1016/j.csda.2014.03.004 
Rossi, S.P.S., Schwaiger, M., Winkler, G, 2005, Managerial behavior and cost/profit efficiency in the banking sectors of Central and Eastern European countries, Working Paper 96, Oesterreichische Nationalbank.

Rubin, D.B., 1987, The calculation of posterior distributions by data augmentation: Comment: A noniterative sampling/importance resampling alternative to the data augmentation algorithm for creating a few imputations when fractions of missing information are modest: The SIR algorithm, Journal of the American Statistical Association, 82(398), 543-6. https://doi.org/10.2307/2289460

Sealey, C.W., Lindley, J.T., 1977, Inputs, outputs, and a theory of production and cost at depository financial institutions, The Journal of Finance, 32(4), 1251-66. https://doi.org/10.1111/j.1540$\underline{6261.1977 . t b 03324 . x}$

Staikouras, C., Mamatzakis, E., Koutsomanoli-Filippaki, A., 2008, Cost efficiency of the banking industry in the South Eastern European region, Journal of International Financial Markets, Institutions and Money, 18(5), 483-97. https://doi.org/10.1016/j.intfin.2007.07.003

Tortosa-Ausina, E., Grifell-Tatjé, E., Armero, C., Conesa, D., 2008, Sensitivity analysis of efficiency and Malmquist productivity indices: An application to Spanish savings banks, European Journal of Operational Research, 184(3), 1062-84. https://doi.org/10.1016/j.ejor.2006.11.035

Tsionas, E.G., Assaf, A.G., Matousek, R., 2015, Dynamic technical and allocative efficiencies in European banking, Journal of Banking \& Finance, 52, 130-9.

https://doi.org/10.1016/j.jbankfin.2014.11.007

Weill, L., 2009, Convergence in banking efficiency across European countries, Journal of International Financial Markets, Institutions and Money, 19(5), 818-33. https://doi.org/10.1016/j.intfin.2009.05.002 
Table 1: Means and standard deviations of the main variables, 2008-2015

\begin{tabular}{|c|c|c|c|c|c|c|c|c|c|}
\hline Country & $\begin{array}{c}\text { Costs / } \\
\text { Assets } \\
(\%)\end{array}$ & $\begin{array}{c}\text { Revenu } \\
\text { e / } \\
\text { Assets } \\
(\%)\end{array}$ & $\begin{array}{c}\text { Loans / } \\
\text { Assets } \\
(\%)\end{array}$ & $\begin{array}{c}\text { OEA / } \\
\text { Assets } \\
(\%)\end{array}$ & $\begin{array}{c}\text { Equity / } \\
\text { Assets } \\
(\%)\end{array}$ & $\begin{array}{c}\text { Price of } \\
\text { Labor } \\
(\%)\end{array}$ & $\begin{array}{c}\text { Price of } \\
\text { Deposit } \\
\text { s (\%) }\end{array}$ & $\begin{array}{c}\text { Price of } \\
\text { Capital } \\
(\%)\end{array}$ & $\mathbf{N}$ \\
\hline Austria & $\begin{array}{c}4.00 \\
(0.90)\end{array}$ & $\begin{array}{c}5.00 \\
(1.20)\end{array}$ & $\begin{array}{c}56.90 \\
(15.30)\end{array}$ & $\begin{array}{c}39.00 \\
(15.10)\end{array}$ & $\begin{array}{c}7.60 \\
(3.00)\end{array}$ & $\begin{array}{c}1.20 \\
(0.40)\end{array}$ & $\begin{array}{c}2.40 \\
(1.20)\end{array}$ & $\begin{array}{c}88.00 \\
(114.40)\end{array}$ & 1,278 \\
\hline Belgium & $\begin{array}{c}4.50 \\
(1.50)\end{array}$ & $\begin{array}{c}5.20 \\
(1.80)\end{array}$ & $\begin{array}{c}47.50 \\
(19.70)\end{array}$ & $\begin{array}{c}48.10 \\
(19.10)\end{array}$ & $\begin{array}{c}7.00 \\
(5.70)\end{array}$ & $\begin{array}{c}1.00 \\
(0.70)\end{array}$ & $\begin{array}{c}3.50 \\
(2.00)\end{array}$ & $\begin{array}{c}196.20 \\
(222.30)\end{array}$ & 87 \\
\hline Denmark & $\begin{array}{c}5.00 \\
(1.00)\end{array}$ & $\begin{array}{c}6.60 \\
(1.20)\end{array}$ & $\begin{array}{c}61.80 \\
(11.10)\end{array}$ & $\begin{array}{c}31.30 \\
(11.80)\end{array}$ & $\begin{array}{l}13.10 \\
(4.80)\end{array}$ & $\begin{array}{c}1.80 \\
(0.60)\end{array}$ & $\begin{array}{c}2.30 \\
(1.10)\end{array}$ & $\begin{array}{c}154.40 \\
(162.70)\end{array}$ & 464 \\
\hline Finland & $\begin{array}{c}3.80 \\
(1.50)\end{array}$ & $\begin{array}{c}4.60 \\
(1.60)\end{array}$ & $\begin{array}{c}63.60 \\
(21.40)\end{array}$ & $\begin{array}{c}30.70 \\
(18.60)\end{array}$ & $\begin{array}{c}7.70 \\
(2.40)\end{array}$ & $\begin{array}{c}0.80 \\
(0.60)\end{array}$ & $\begin{array}{c}3.50 \\
(2.30)\end{array}$ & $\begin{array}{c}243.00 \\
(208.90)\end{array}$ & 39 \\
\hline France & $\begin{array}{c}4.50 \\
(1.10)\end{array}$ & $\begin{array}{c}5.60 \\
(1.30)\end{array}$ & $\begin{array}{c}64.20 \\
(18.60)\end{array}$ & $\begin{array}{c}30.70 \\
(18.40)\end{array}$ & $\begin{array}{c}8.90 \\
(4.50)\end{array}$ & $\begin{array}{c}1.20 \\
(0.60)\end{array}$ & $\begin{array}{c}3.00 \\
(1.40)\end{array}$ & $\begin{array}{c}164.40 \\
(138.10)\end{array}$ & 931 \\
\hline Germany & $\begin{array}{c}4.50 \\
(0.70)\end{array}$ & $\begin{array}{c}5.50 \\
(0.70)\end{array}$ & $\begin{array}{c}57.90 \\
(12.80)\end{array}$ & $\begin{array}{c}37.50 \\
(12.80)\end{array}$ & $\begin{array}{c}6.50 \\
(2.00)\end{array}$ & $\begin{array}{c}1.40 \\
(0.40)\end{array}$ & $\begin{array}{c}2.50 \\
(0.60)\end{array}$ & $\begin{array}{c}86.40 \\
(85.00)\end{array}$ & 10,693 \\
\hline Greece & $\begin{array}{c}4.90 \\
(1.20)\end{array}$ & $\begin{array}{c}6.20 \\
(1.30)\end{array}$ & $\begin{array}{c}68.90 \\
(10.60)\end{array}$ & $\begin{array}{c}23.10 \\
(10.50)\end{array}$ & $\begin{array}{c}7.90 \\
(4.50)\end{array}$ & $\begin{array}{c}1.30 \\
(0.50)\end{array}$ & $\begin{array}{c}3.20 \\
(1.40)\end{array}$ & $\begin{array}{c}109.90 \\
(90.00)\end{array}$ & 96 \\
\hline Ireland & $\begin{array}{c}3.70 \\
(1.10)\end{array}$ & $\begin{array}{c}4.60 \\
(1.40)\end{array}$ & $\begin{array}{l}67.30 \\
(8.90)\end{array}$ & $\begin{array}{l}29.50 \\
(8.50)\end{array}$ & $\begin{array}{c}6.50 \\
(5.50)\end{array}$ & $\begin{array}{c}0.60 \\
(0.30)\end{array}$ & $\begin{array}{c}3.70 \\
(1.50)\end{array}$ & $\begin{array}{c}208.90 \\
(183.10)\end{array}$ & 37 \\
\hline Italy & $\begin{array}{l}4.10 \\
(0.80)\end{array}$ & $\begin{array}{c}5.30 \\
(1.10)\end{array}$ & $\begin{array}{c}68.40 \\
(13.30)\end{array}$ & $\begin{array}{c}26.70 \\
(13.00)\end{array}$ & $\begin{array}{l}11.30 \\
(4.00)\end{array}$ & $\begin{array}{c}1.40 \\
(0.30)\end{array}$ & $\begin{array}{c}3.00 \\
(1.60)\end{array}$ & $\begin{array}{c}105.20 \\
(115.30)\end{array}$ & 3,390 \\
\hline Luxembourg & $\begin{array}{c}4.10 \\
(1.70)\end{array}$ & $\begin{array}{c}5.30 \\
(2.30)\end{array}$ & $\begin{array}{c}33.80 \\
(18.40)\end{array}$ & $\begin{array}{c}61.70 \\
(18.20)\end{array}$ & $\begin{array}{c}6.70 \\
(5.30)\end{array}$ & $\begin{array}{c}0.90 \\
(0.70)\end{array}$ & $\begin{array}{c}3.00 \\
(1.70)\end{array}$ & $\begin{array}{c}286.80 \\
(255.60)\end{array}$ & 167 \\
\hline Netherlands & $\begin{array}{c}4.70 \\
(1.70)\end{array}$ & $\begin{array}{l}5.70 \\
(2.10)\end{array}$ & $\begin{array}{c}57.60 \\
(21.00)\end{array}$ & $\begin{array}{c}34.20 \\
(18.50)\end{array}$ & $\begin{array}{c}7.50 \\
(3.70)\end{array}$ & $\begin{array}{c}0.90 \\
(0.50)\end{array}$ & $\begin{array}{l}4.30 \\
(2.10)\end{array}$ & $\begin{array}{c}157.80 \\
(163.30)\end{array}$ & 87 \\
\hline Portugal & $\begin{array}{c}4.60 \\
(1.30)\end{array}$ & $\begin{array}{c}5.40 \\
(1.40)\end{array}$ & $\begin{array}{c}60.00 \\
(20.30)\end{array}$ & $\begin{array}{c}33.10 \\
(20.70)\end{array}$ & $\begin{array}{c}8.80 \\
(6.80)\end{array}$ & $\begin{array}{l}1.10 \\
(0.60)\end{array}$ & $\begin{array}{c}3.70 \\
(1.90)\end{array}$ & $\begin{array}{c}193.50 \\
(207.70)\end{array}$ & 105 \\
\hline Spain & $\begin{array}{c}3.50 \\
(0.90)\end{array}$ & $\begin{array}{c}4.60 \\
(1.00)\end{array}$ & $\begin{array}{c}71.70 \\
(12.20)\end{array}$ & $\begin{array}{c}23.10 \\
(12.00)\end{array}$ & $\begin{array}{c}8.90 \\
(3.80)\end{array}$ & $\begin{array}{c}0.90 \\
(0.40)\end{array}$ & $\begin{array}{c}2.50 \\
(1.20)\end{array}$ & $\begin{array}{c}48.70 \\
(63.70)\end{array}$ & 709 \\
\hline Sweden & $\begin{array}{c}3.50 \\
(0.80)\end{array}$ & $\begin{array}{l}5.10 \\
(0.90)\end{array}$ & $\begin{array}{c}74.90 \\
(11.10)\end{array}$ & $\begin{array}{c}22.40 \\
(10.90)\end{array}$ & $\begin{array}{l}14.20 \\
(4.90)\end{array}$ & $\begin{array}{l}1.20 \\
(0.30)\end{array}$ & $\begin{array}{c}1.60 \\
(1.00)\end{array}$ & $\begin{array}{c}200.20 \\
(156.50)\end{array}$ & 439 \\
\hline UK & $\begin{array}{c}4.00 \\
(1.60)\end{array}$ & $\begin{array}{l}5.20 \\
(2.10)\end{array}$ & $\begin{array}{c}47.20 \\
(18.50)\end{array}$ & $\begin{array}{c}47.00 \\
(19.70)\end{array}$ & $\begin{array}{c}9.40 \\
(6.50)\end{array}$ & $\begin{array}{c}0.90 \\
(0.50)\end{array}$ & $\begin{array}{c}3.10 \\
(1.80)\end{array}$ & $\begin{array}{c}247.40 \\
(209.80)\end{array}$ & 291 \\
\hline EU-15 & $\begin{array}{c}4.30 \\
(0.90)\end{array}$ & $\begin{array}{c}5.40 \\
(1.00)\end{array}$ & $\begin{array}{c}60.70 \\
(14.90)\end{array}$ & $\begin{array}{c}34.60 \\
(14.80)\end{array}$ & $\begin{array}{c}8.00 \\
(3.90)\end{array}$ & $\begin{array}{c}1.30 \\
(0.40)\end{array}$ & $\begin{array}{c}2.60 \\
(1.10)\end{array}$ & $\begin{array}{c}103.10 \\
(115.20)\end{array}$ & 18,831 \\
\hline
\end{tabular}

Notes: The table presents the means and standard deviations of the main variables used in our analysis. Assets $=$ total assets, loans $=$ net loans, capital $=$ physical capital, OEA $=$ other earned assets, and $\mathrm{N}=$ number of observations. Source: Bankscope database and author's calculations. 
Table 2: Posterior means and standard deviations of parameters of interest in MIMIC model

\begin{tabular}{|c|c|c|}
\hline \multicolumn{2}{|c|}{ Parameters of Interest } & \multirow{2}{*}{$\begin{array}{c}\text { All Banks } \\
0.232 \\
(0.022)\end{array}$} \\
\hline \multirow{4}{*}{ Elasticities } & Physical Capital & \\
\hline & Labor & $\begin{array}{c}0.344 \\
(0.037)\end{array}$ \\
\hline & Deposits & $\begin{array}{c}0.412 \\
(0.045)\end{array}$ \\
\hline & $\begin{array}{l}\text { Other Earned } \\
\text { Assets }\end{array}$ & $\begin{array}{l}-0.781 \\
(0.038)\end{array}$ \\
\hline \multicolumn{2}{|c|}{ Returns to Scale } & $\begin{array}{c}1.013 \\
(0.045)\end{array}$ \\
\hline \multicolumn{2}{|c|}{ Technical Inefficiency } & $\begin{array}{c}0.148 \\
(0.014)\end{array}$ \\
\hline \multicolumn{2}{|c|}{ Technical Change } & $\begin{array}{c}-0.0093 \\
(0.004)\end{array}$ \\
\hline \multicolumn{2}{|c|}{ Efficiency Change } & $\begin{array}{l}-0.0075 \\
(0.008)\end{array}$ \\
\hline \multicolumn{2}{|c|}{ Productivity Growth } & $\begin{array}{c}-0.0168 \\
(0.012)\end{array}$ \\
\hline
\end{tabular}

Notes: Full MIMIC model estimates using 50,000 MCMC iterations. 
Table 3: Parameters of interest for larger and smaller banks, and periphery and core EU15 countries

\begin{tabular}{|c|c|c|c|c|c|}
\hline \multicolumn{2}{|c|}{$\begin{array}{l}\text { Parameters of } \\
\text { Interest }\end{array}$} & \multirow{2}{*}{$\begin{array}{c}\begin{array}{c}\text { Larger } \\
\text { Banks }\end{array} \\
0.317 \\
(0.044)\end{array}$} & \multirow{2}{*}{$\begin{array}{c}\begin{array}{c}\text { Smaller } \\
\text { Banks }\end{array} \\
0.221 \\
(0.015)\end{array}$} & \multirow{2}{*}{$\begin{array}{c}\begin{array}{c}\text { EU-15 } \\
\text { "Periphery" }\end{array} \\
0.412 \\
(0.022)\end{array}$} & \multirow{2}{*}{$\begin{array}{c}\begin{array}{c}\text { Rest of } \\
\text { EU-15 }\end{array} \\
0.613 \\
(0.028)\end{array}$} \\
\hline & Labor & & & & \\
\hline \multirow[t]{3}{*}{ Elasticities } & Physical Capital & $\begin{array}{c}0.221 \\
(0.072)\end{array}$ & $\begin{array}{c}0.305 \\
(0.081)\end{array}$ & $\begin{array}{c}0.303 \\
(0.035)\end{array}$ & $\begin{array}{c}0.496 \\
(0.023)\end{array}$ \\
\hline & Deposits & $\begin{array}{c}0.503 \\
(0.032)\end{array}$ & $\begin{array}{c}0.645 \\
(0.050)\end{array}$ & $\begin{array}{c}0.255 \\
(0.019)\end{array}$ & $\begin{array}{c}0.470 \\
(0.016)\end{array}$ \\
\hline & $\begin{array}{l}\text { Other Earned } \\
\text { Assets }\end{array}$ & $\begin{array}{l}-0.425 \\
(0.027)\end{array}$ & $\begin{array}{l}-0.120 \\
(0.032)\end{array}$ & $\begin{array}{l}-0.322 \\
(0.027)\end{array}$ & $\begin{array}{l}-0.517 \\
(0.033)\end{array}$ \\
\hline \multicolumn{2}{|c|}{ Returns to Scale } & $\begin{array}{c}1.041 \\
(0.032)\end{array}$ & $\begin{array}{c}1.171 \\
(0.016)\end{array}$ & $\begin{array}{c}0.970 \\
(0.012)\end{array}$ & $\begin{array}{c}0.985 \\
(0.017)\end{array}$ \\
\hline \multicolumn{2}{|c|}{ Technical Inefficiency } & $\begin{array}{c}0.251 \\
(0.133)\end{array}$ & $\begin{array}{c}0.310 \\
(0.089)\end{array}$ & $\begin{array}{c}0.282 \\
(0.133)\end{array}$ & $\begin{array}{c}0.133 \\
(0.089)\end{array}$ \\
\hline \multicolumn{2}{|c|}{ Technical Change } & $\begin{array}{l}-0.005 \\
(0.003)\end{array}$ & $\begin{array}{c}-0.011 \\
(0.002)\end{array}$ & $\begin{array}{c}-0.012 \\
(0.0032)\end{array}$ & $\begin{array}{c}0.010 \\
(0.0025)\end{array}$ \\
\hline \multicolumn{2}{|c|}{ Efficiency Change } & $\begin{array}{l}-0.025 \\
(0.012)\end{array}$ & $\begin{array}{l}-0.036 \\
(0.008)\end{array}$ & $\begin{array}{l}-0.025 \\
(0.012)\end{array}$ & $\begin{array}{c}0.017 \\
(0.0044)\end{array}$ \\
\hline \multicolumn{2}{|c|}{ Productivity Growth } & $\begin{array}{l}-0.030 \\
(0.012)\end{array}$ & $\begin{array}{l}-0.047 \\
(0.022)\end{array}$ & $\begin{array}{l}-0.037 \\
(0.010)\end{array}$ & $\begin{array}{c}0.017 \\
(0.006)\end{array}$ \\
\hline
\end{tabular}

Notes: The entries are the posterior means and standard deviations (in parentheses) of the parameters based on 50,000 MCMC iterations of the full MCMC model. Large banks are those with total assets above the median. The EU-15 "periphery" consist of Greece, Ireland, Italy, Portugal and Spain. 
Table 4: Posterior means and standard deviations for factor loadings, and marginal efficiency effects in full MIMIC model

\begin{tabular}{|c|c|c|c|c|c|}
\hline & $\begin{array}{c}\text { Commercial } \\
\text { Banks }\end{array}$ & $\begin{array}{l}\text { Cooperative } \\
\text { Banks }\end{array}$ & $\begin{array}{c}\text { Savings } \\
\text { Banks }\end{array}$ & $\begin{array}{l}\text { Investment } \\
\text { Banks }\end{array}$ & $\begin{array}{c}\text { Real } \\
\text { Estate } \\
\text { Banks }\end{array}$ \\
\hline & \multicolumn{5}{|c|}{ MIMIC Equation Loadings } \\
\hline $\begin{array}{l}\text { Return on Assets } \\
(R O A)\end{array}$ & $\begin{array}{l}-0.045 \\
(0.012)\end{array}$ & $\begin{array}{l}-0.033 \\
(0.017)\end{array}$ & $\begin{array}{l}-0.041 \\
(0.015)\end{array}$ & $\begin{array}{l}-0.717 \\
(0.014)\end{array}$ & $\begin{array}{l}-0.072 \\
(0.015)\end{array}$ \\
\hline $\begin{array}{l}\text { Return on Equity } \\
(R O E)\end{array}$ & $\begin{array}{l}-0.017 \\
(0.0081)\end{array}$ & $\begin{array}{r}-0.081 \\
(0.035)\end{array}$ & $\begin{array}{l}-0.023 \\
(0.0044)\end{array}$ & $\begin{array}{l}-0.551 \\
(0.013)\end{array}$ & $\begin{array}{l}-0.044 \\
(0.008)\end{array}$ \\
\hline Equity-to-Assets & $\begin{array}{l}-0.013 \\
(0.008)\end{array}$ & $\begin{array}{l}-0.028 \\
(0.005)\end{array}$ & $\begin{array}{l}-0.035 \\
(0.007)\end{array}$ & $\begin{array}{l}-0.047 \\
(0.012)\end{array}$ & $\begin{array}{l}-0.065 \\
(0.017)\end{array}$ \\
\hline Z-Score & $\begin{array}{l}-0.057 \\
(0.013)\end{array}$ & $\begin{array}{l}-0.032 \\
(0.014)\end{array}$ & $\begin{array}{l}-0.048 \\
(0.012)\end{array}$ & $\begin{array}{l}-0.044 \\
(0.007)\end{array}$ & $\begin{array}{l}-0.122 \\
(0.016)\end{array}$ \\
\hline \multirow[t]{2}{*}{ Log $R O A$ Volatility } & $\begin{array}{l}0.012 \\
(0.003) \\
\end{array}$ & $\begin{array}{l}0.037 \\
(0.005) \\
\end{array}$ & $\begin{array}{l}0.025 \\
(0.005) \\
\end{array}$ & $\begin{array}{l}0.081 \\
(0.012) \\
\end{array}$ & $\begin{array}{l}0.044 \\
(0.007) \\
\end{array}$ \\
\hline & \multicolumn{5}{|c|}{ Marginal Efficiency Effects } \\
\hline Ln Price of Labor & $\begin{array}{l}0.032 \\
(0.007)\end{array}$ & $\begin{array}{l}0.015 \\
(0.009)\end{array}$ & $\begin{array}{l}0.044 \\
(0.011)\end{array}$ & $\begin{array}{l}0.055 \\
(0.011)\end{array}$ & $\begin{array}{l}0.061 \\
(0.013)\end{array}$ \\
\hline $\begin{array}{l}\text { Ln Price of Physical } \\
\text { Capital }\end{array}$ & $\begin{array}{l}0.081 \\
(0.012)\end{array}$ & $\begin{array}{l}0.032 \\
(0.018)\end{array}$ & $\begin{array}{l}0.093 \\
(0.005)\end{array}$ & $\begin{array}{l}0.121 \\
(0.013)\end{array}$ & $\begin{array}{l}0.224 \\
(0.013)\end{array}$ \\
\hline Ln Price of Deposits & $\begin{array}{l}0.075 \\
(0.017)\end{array}$ & $\begin{array}{l}0.041 \\
(0.012)\end{array}$ & $\begin{array}{l}0.095 \\
(0.007)\end{array}$ & $\begin{array}{l}0.144 \\
(0.022)\end{array}$ & $\begin{array}{l}0.188 \\
(0.021)\end{array}$ \\
\hline Ln Price of Loans & $\begin{array}{l}-0.315 \\
(0.027)\end{array}$ & $\begin{array}{l}-0.222 \\
(0.015)\end{array}$ & $\begin{array}{l}-0.446 \\
(0.013)\end{array}$ & $\begin{array}{l}-0.527 \\
(0.013)\end{array}$ & $\begin{array}{l}-0.672 \\
(0.013)\end{array}$ \\
\hline Ln Price of OEA & $\begin{array}{l}-0.415 \\
(0.009)\end{array}$ & $\begin{array}{l}-0.188 \\
(0.013)\end{array}$ & $\begin{array}{l}-0.322 \\
(0.010)\end{array}$ & $\begin{array}{l}-0.884 \\
(0.014)\end{array}$ & $\begin{array}{l}-0.710 \\
(0.015)\end{array}$ \\
\hline Bank Age & $\begin{array}{c}-0.024 \\
(0.003)\end{array}$ & $\begin{array}{r}-0.031 \\
(0.012)\end{array}$ & $\begin{array}{r}-0.045 \\
(0.011)\end{array}$ & $\begin{array}{r}-0.052 \\
(0.014)\end{array}$ & $\begin{array}{l}-0.033 \\
(0.005)\end{array}$ \\
\hline Time Trend & $\begin{array}{c}-0.0014 \\
(0.0015)\end{array}$ & $\begin{array}{r}-0.0011 \\
(0.0011)\end{array}$ & $\begin{array}{l}0.0017 \\
(0.0012)\end{array}$ & $\begin{array}{r}-0.0012 \\
(0.0011)\end{array}$ & $\begin{array}{r}-0.0011 \\
(0.0010)\end{array}$ \\
\hline
\end{tabular}

Notes: OEA $=$ other earned assets. The MIMIC factor loadings $\lambda$ in equation (5) are shown in the top panel. The $\mathrm{Z}$ score equals $\left(R O A+\frac{E q u i t y}{A s s e t s}\right) / \sigma_{R O A}$. The marginal efficiency effects are calculated as $\partial \ln E u_{i t} / \partial z_{q t}$, where $z_{q}$ is the log of the price of labor, physical capital etc. The table entries are the posterior means and standard deviations (in parentheses) in the full MIMIC model using 50,000 MCMC iterations. 
Table 5: The effect of dropping an indicator on key parameters of interest

\begin{tabular}{|c|c|c|c|c|c|c|}
\hline \multirow{2}{*}{$\begin{array}{l}\text { Parameters of } \\
\text { Interest }\end{array}$} & \multirow{2}{*}{$\begin{array}{l}\text { All Five } \\
\text { Indicators }\end{array}$} & \multicolumn{5}{|c|}{ Omitted Indicator } \\
\hline & & ROA & ROE & $\begin{array}{l}\text { Equity/ } \\
\text { Asset }\end{array}$ & Z-Score & $\begin{array}{c}\text { ROA } \\
\text { Volatility }\end{array}$ \\
\hline & & \multicolumn{5}{|c|}{$\begin{array}{c}\text { Percentage Difference Relative to Five Indicator } \\
\text { Model }\end{array}$} \\
\hline Returns to Scale & 1.013 & $\begin{array}{l}+1.2 \% \\
(2.1)\end{array}$ & $\begin{array}{c}+1.5 \% \\
(1.3)\end{array}$ & $\begin{array}{l}-18.8 \% \\
(2.3)\end{array}$ & $\begin{array}{l}-17.1 \% \\
(1.5)\end{array}$ & $\begin{array}{c}-10.1 \% \\
(3.5)\end{array}$ \\
\hline Technical Inefficiency & 0.148 & $\begin{array}{l}+1.7 \% \\
(0.5)\end{array}$ & $\begin{array}{l}+1.2 \% \\
\quad(0.2)\end{array}$ & $\begin{array}{c}-10.3 \% \\
(4.4)\end{array}$ & $\begin{array}{l}-17.5 \% \\
\quad(4.4)\end{array}$ & $\begin{array}{l}+8.5 \% \\
\quad(1.2)\end{array}$ \\
\hline Efficiency Change & -0.0093 & $\begin{array}{c}+1.2 \% \\
(7.0)\end{array}$ & $\begin{array}{c}+2.2 \% \\
(4.3)\end{array}$ & $\begin{array}{l}-1.5 \% \\
(0.7)\end{array}$ & $\begin{array}{c}-3.3 \% \\
(1.3)\end{array}$ & $\begin{array}{c}-2.2 \% \\
(0.6)\end{array}$ \\
\hline Technical Change & -0.0075 & $\begin{array}{c}+3.5 \% \\
(0.1)\end{array}$ & $\begin{array}{c}+2.2 \% \\
(0.1)\end{array}$ & $\begin{array}{l}-1.1 \% \\
(0.3)\end{array}$ & $\begin{array}{c}-1.5 \% \\
(0.4)\end{array}$ & $\begin{array}{l}5.2 \% \\
(0.1)\end{array}$ \\
\hline Productivity Growth & -0.0168 & $\begin{array}{c}+4.7 \% \\
(5.3)\end{array}$ & $\begin{array}{c}+4.4 \% \\
(3.9)\end{array}$ & $\begin{array}{c}-2.6 \% \\
(0.6)\end{array}$ & $\begin{array}{c}-3.8 \% \\
(1.0)\end{array}$ & $\begin{array}{c}+3.0 \% \\
(0.5)\end{array}$ \\
\hline
\end{tabular}

Notes: The table entries are the posterior means and standard deviations (in parentheses) of the percentage differences in the parameters of interest when the specified indicator is dropped from the full MIMIC model. The calculations are based on 50,000 MCMC iterations. 
Figure 1: The posterior densities of the labor, capital and deposits (input) and other earned assets (output) elasticities in models I, II and the full MIMIC model
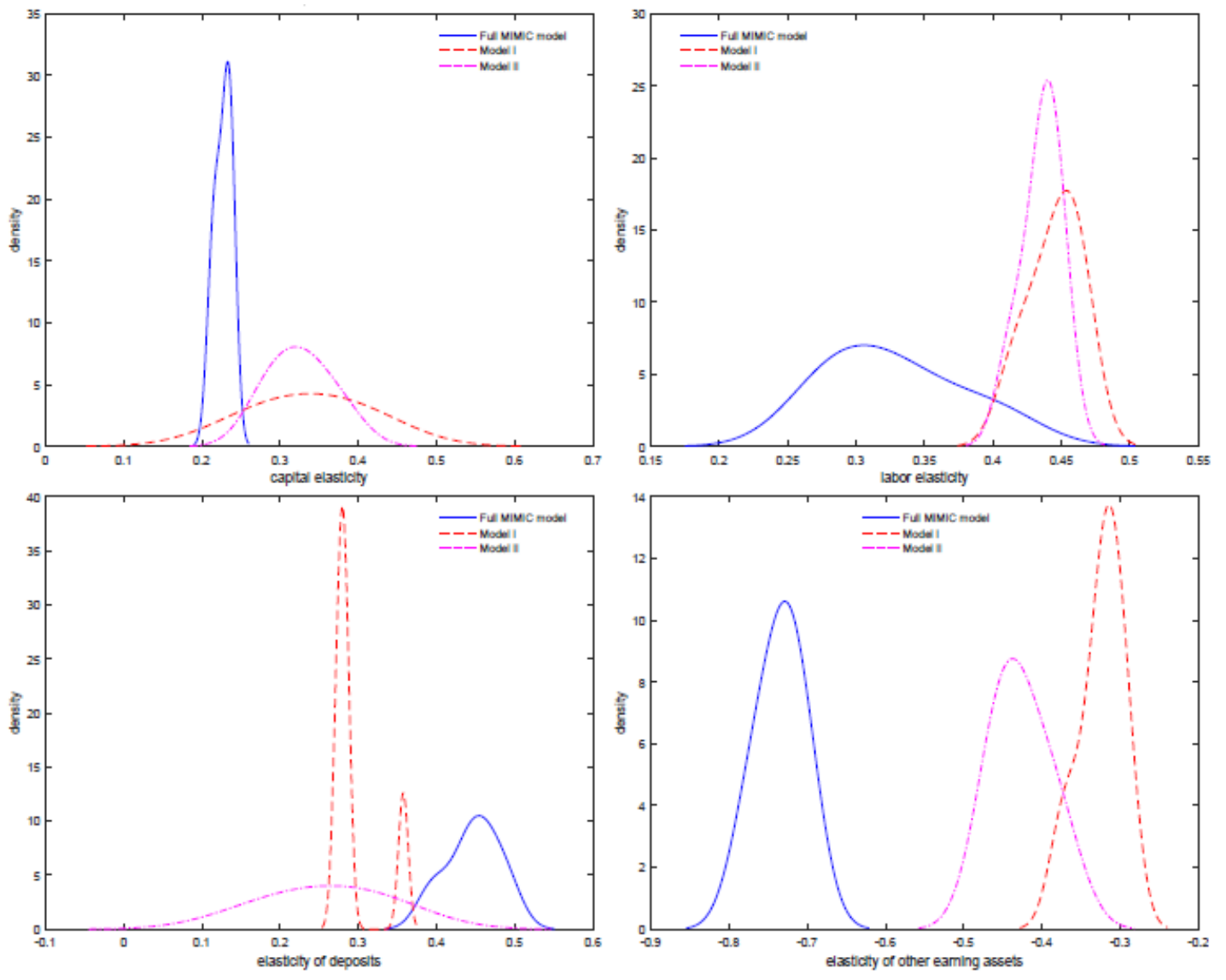
Figure 2: The posterior densities of returns to scale in models I, II and the full MIMIC model

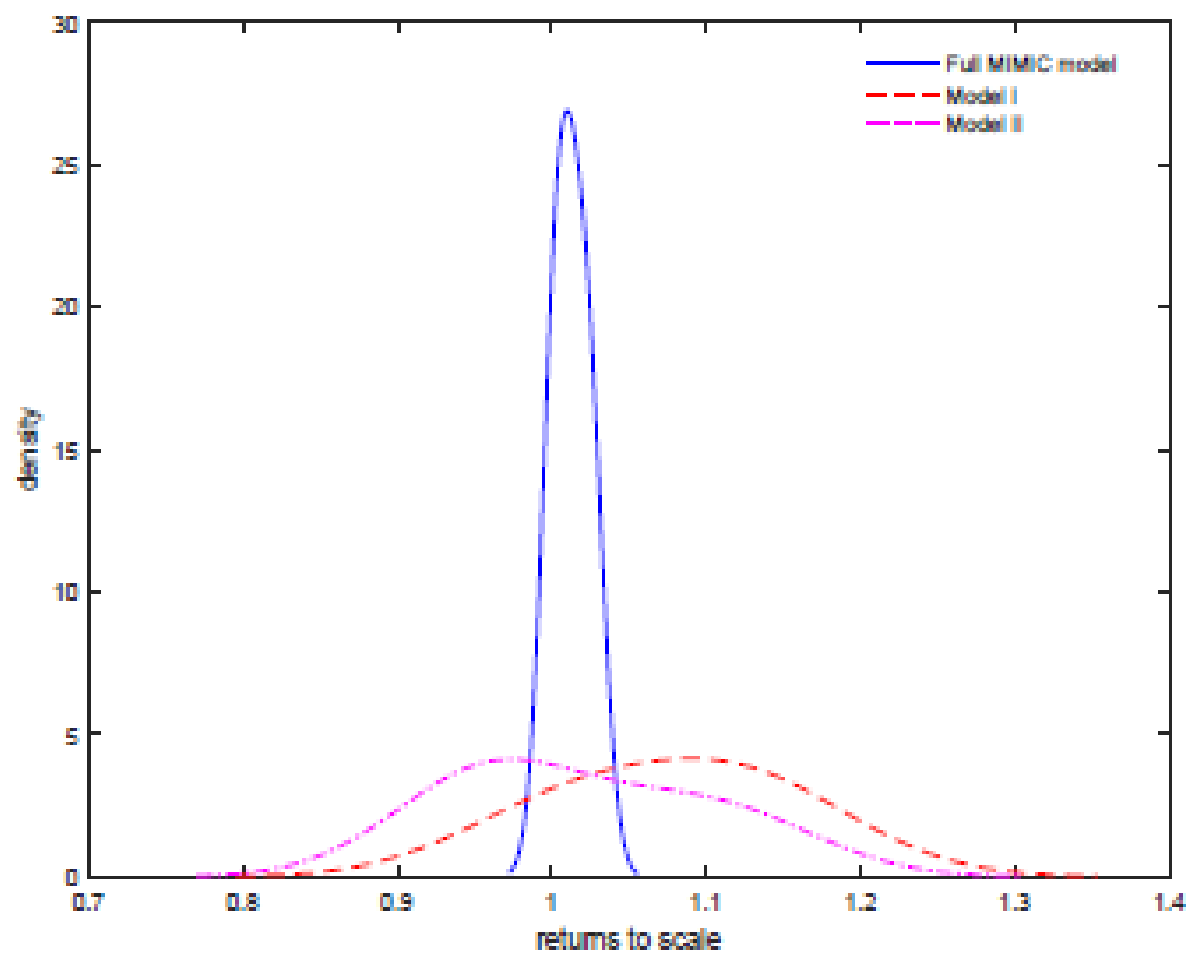


Figure 3: The posterior distributions of technical efficiency, efficiency change, technical change and productivity growth
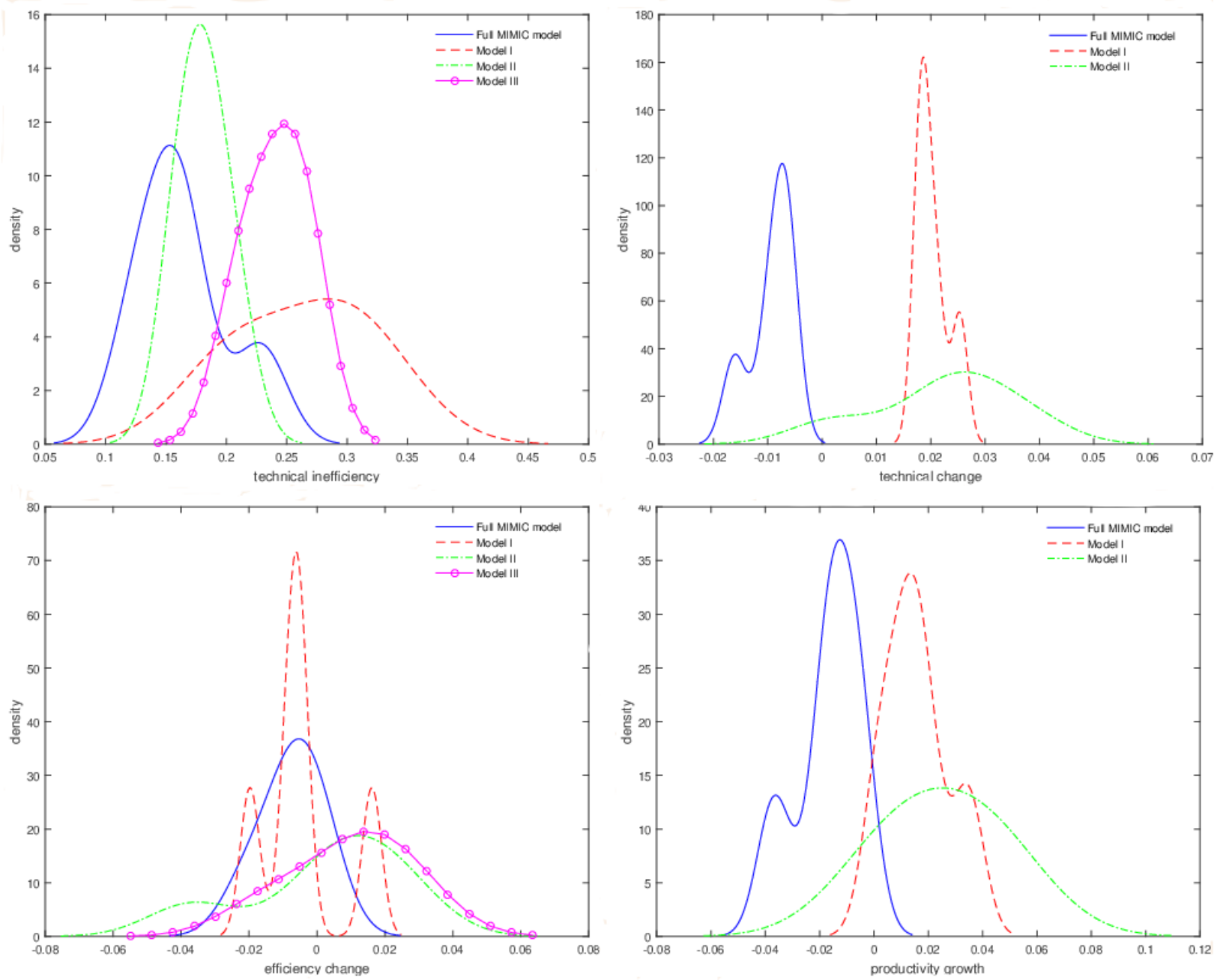
Figure 4: Bayes factors in favor of full MIMIC model

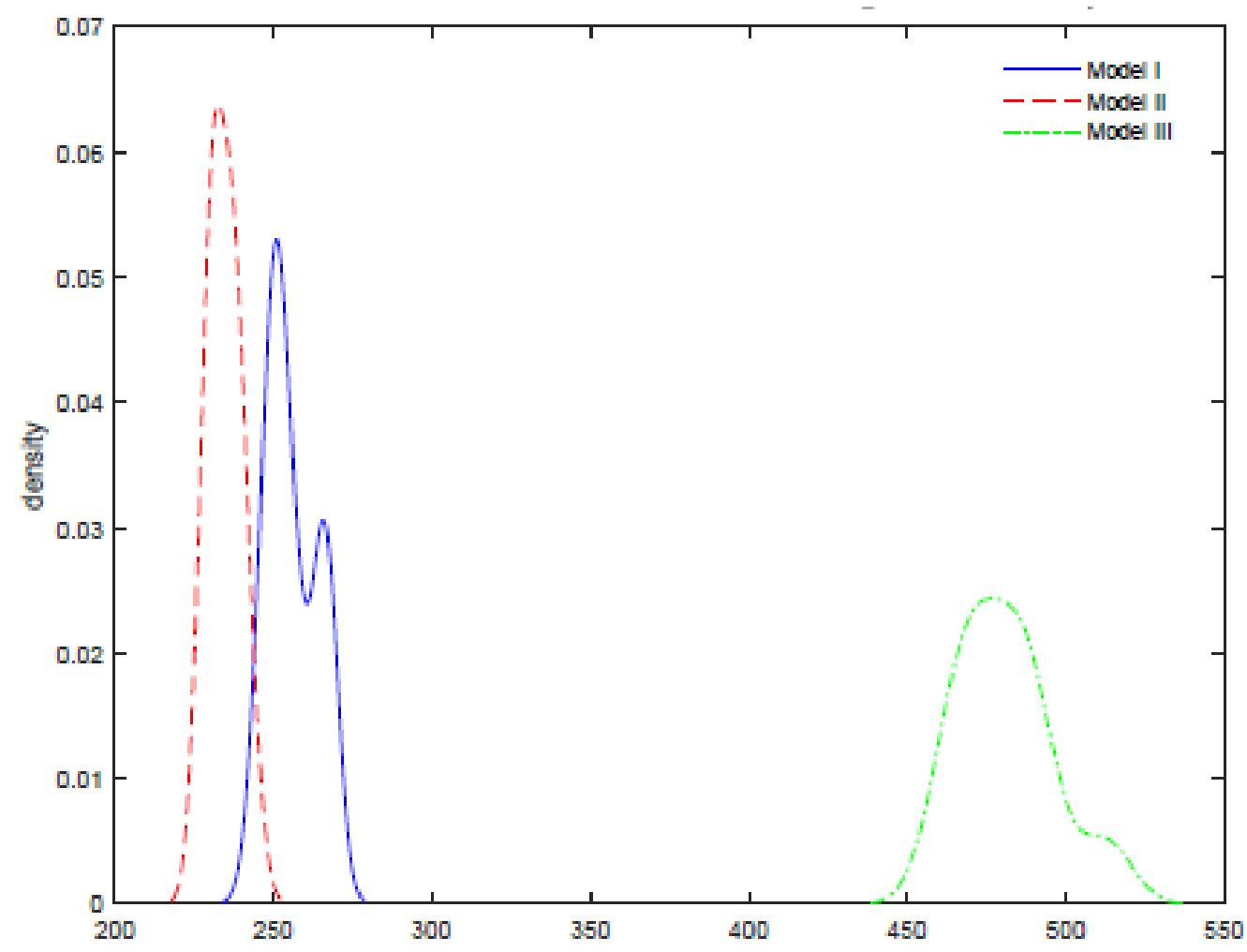

Notes: Technical efficiency $=\tilde{u}_{i t}$. Productivity growth equals the sum of efficiency change and technical change, $P G_{i t}=E C_{i t}+T C_{i t}$. The change in efficiency $E C_{i t}=\triangle \tilde{r}_{i t}$, where $\tilde{r}_{i t}=$ $\exp \left(\tilde{u}_{i t}\right)$, and technical change $T C_{i t}=\partial f\left(x_{i t} ; \beta\right) / \partial t$. 
Figure 5: Densities of $\triangle L P S$, the log predictive scores of models I, II and III relative to the full MIMIC model

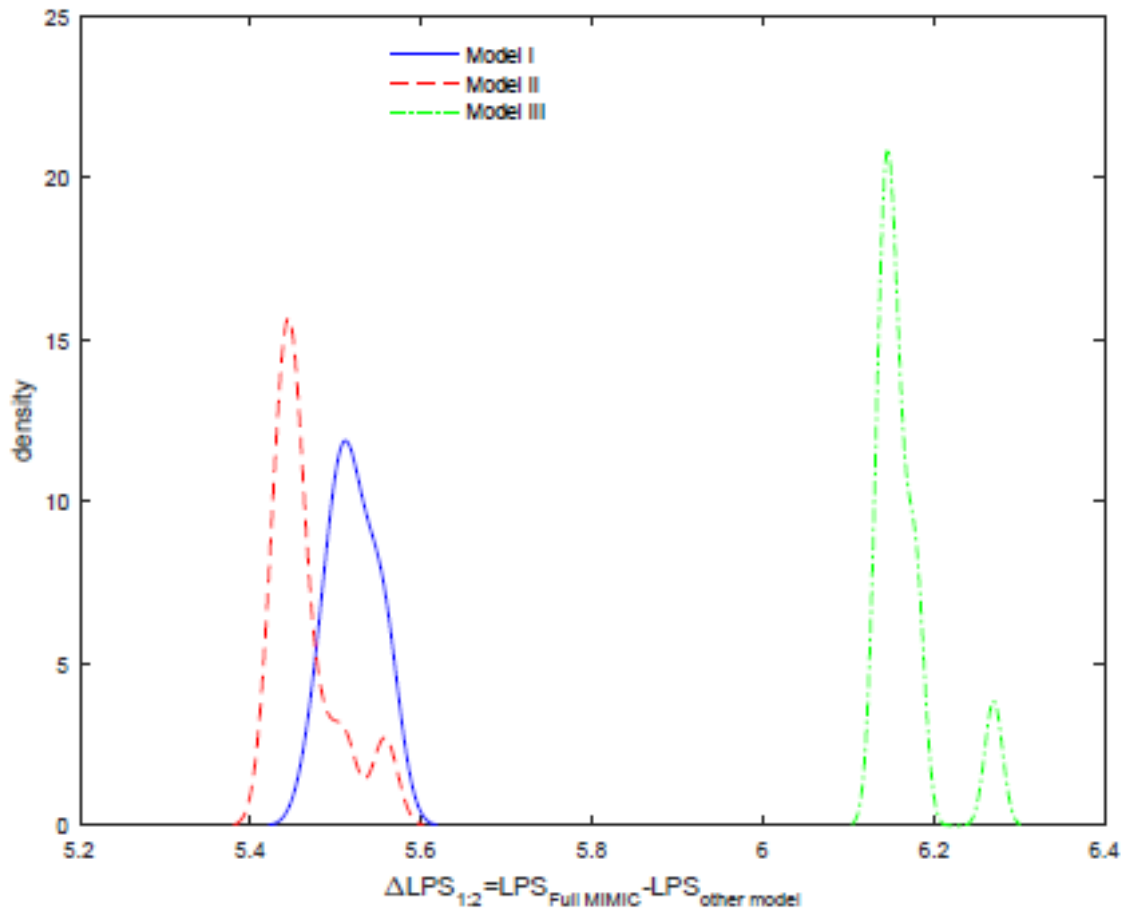


Figure 6: Bayes factors in favor of models with fewer than five MIMIC indicators

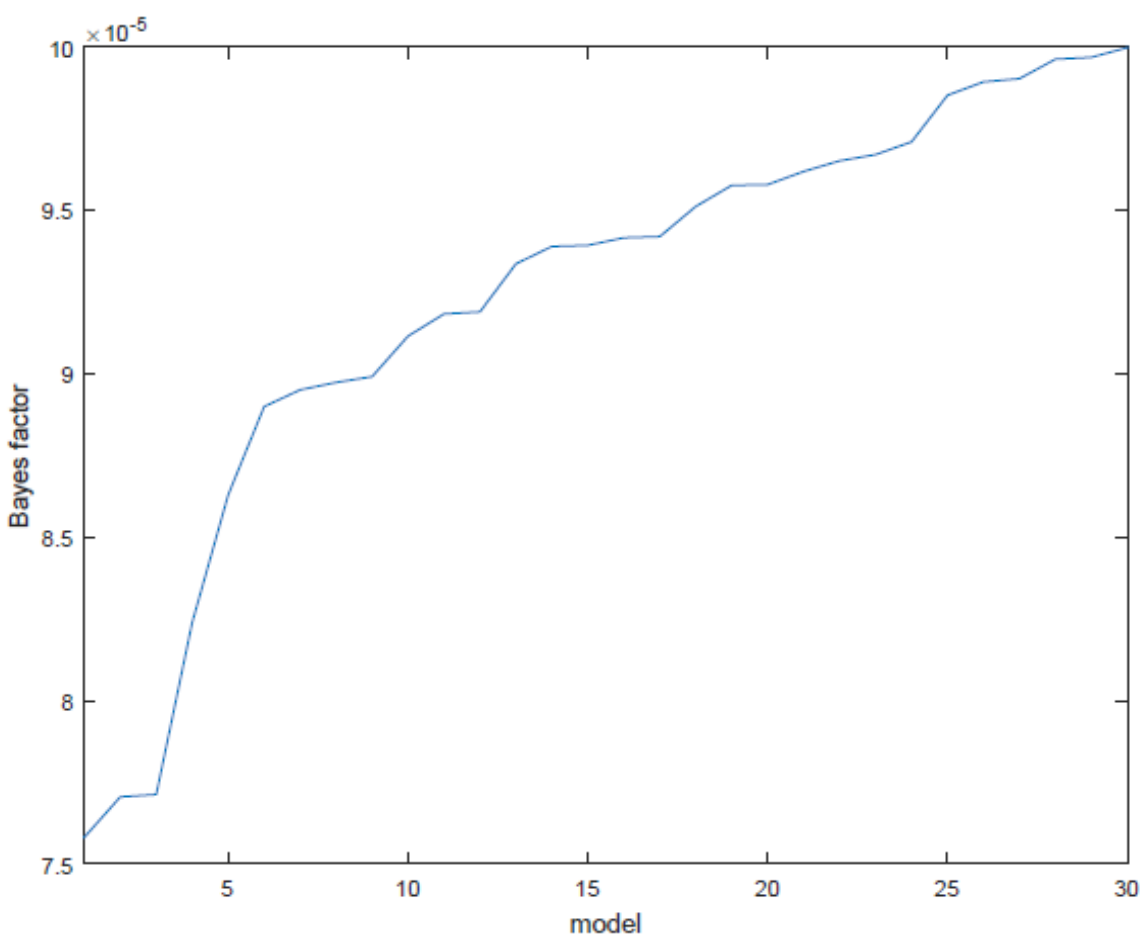

